\title{
Neural bases of Frustration-Aggression Theory: A multi-domain meta-analysis of functional neuroimaging studies.
}

Jules R. Dugré, MSc ${ }^{1,2} \&$ Stéphane Potvin, $\mathrm{PhD}^{1,2}$

${ }^{1}$ Centre de recherche de l'Institut Universitaire en Santé Mentale de Montréal, Montréal, Canada

${ }^{2}$ Department of Psychiatry and Addiction, Faculty of Medicine, University of Montreal, Montréal, Canada

\section{Corresponding author}

Jules R. Dugré \& Stéphane Potvin, PhD; Centre de recherche de l'Institut Universitaire en Santé Mentale de Montréal; 7331 Hochelaga, Montreal, Quebec, Canada; H1N 3V2; Tel. : 514-2514015; Emails: jules.dugre@ umontreal.ca \& stephane.potvin@umontreal.ca 


\begin{abstract}
Early evidence suggests that unexpected non-reward may increase the risk for aggressive behaviors. Despite the growing interest in understanding brain functions that may be implicated in aggressive behaviors, the neural processes underlying such frustrative events remain largely unknown. Furthermore, meta-analytic results have produced discrepant results, potentially due to substantial differences in the definition of anger/aggression constructs. Therefore, coordinatebased meta-analyses on unexpected non-reward and retaliatory behaviors in healthy subjects were conducted. Conjunction analyses were further examined to discover overlapping brain activations across these meta-analytical maps. Frustrative non-reward deactivated the orbitofrontal cortex, ventral striatum and posterior cingulate cortex, whereas increased activations were observed in midcingulo-insular regions, as well as dorsomedial prefrontal cortex, amygdala, thalamus and periaqueductal gray, when using liberal threshold. Retaliation activated of midcingulo-insular regions, the dorsal caudate and the primary somatosensory cortex. Conjunction analyses revealed that both strongly activated midcingulo-insular regions. Our results underscore the role of anterior midcingulate/pre-supplementary motor area and fronto-insular cortex in both frustration and retaliatory behaviors. A neurobiological framework for understanding frustration-based impulsive aggression is provided.
\end{abstract}


medRxiv preprint doi: https://doi.org/10.1101/2021.05.12.21257119; this version posted May 19, 2021. The copyright holder for this preprint (which was not certified by peer review) is the author/funder, who has granted medRxiv a license to display the preprint in perpetuity.

It is made available under a CC-BY-NC 4.0 International license.

\section{Introduction}

Nearly a century ago, Dollard and colleagues proposed that some forms of aggression would appear in an inhibiting context, during which an object would interfere with goal attainment (Dollard, Miller, Doob, Mowrer, \& Sears, 1939), therefore enhancing the risk for aggressive behaviors. In the following years, several researchers have criticized the mutually exclusive relationship between frustration ${ }^{1}$ and aggression, suggesting that frustration may lead to a general negative emotional state (e.g., neuroticism, sadness, anger) and not directly to aggression (Berkowitz, 1989). More precisely, it has been argued that such inhibiting events will lead to aggression if the former context causes sufficient negative affect to enable aggressive inclinations (Berkowitz, 1989). Despite the fact that it has been almost forgotten in current research, the Frustration-Aggression theory remains one of the most prominent theory of aggression.

Reward processing and loss aversion are inherent aspects of human motivation. Neurobiological research has shown a strong implication of ventral striatum, medial OFC/vmPFC and PCC/Precuneus in reward processes (Bartra, McGuire, \& Kable, 2013; Liu, Hairston, Schrier, \& Fan, 2011; Oldham et al., 2018), whereas punishment/loss processing is known to recruit anterior insula/vlPFC and lateral OFC (Bartra et al., 2013; Dugré, Dumais, Bitar, \& Potvin, 2018; Liu et al., 2011; Oldham et al., 2018). Interestingly, receiving offers from someone who follows (or not) social norms may involve reward/punishment processes (7). Indeed, receiving fair monetary offers seems to recruit similar brain regions to those involved in reward processing (e.g., medial OFC/vmPFC, PCC/Precuneus) while receiving unfair monetary offers seems to recruit regions involved in punishment processng (aINS/vlPFC \& lateral OFC),

\footnotetext{
${ }^{1}$ In the current meta-analysis, frustration referred to the inhibiting context during which the expected rewarding object was not obtained due to blockage/interference of goal attainment.
} 
medRxiv preprint doi: https://doi.org/10.1101/2021.05.12.21257119; this version posted May 19, 2021. The copyright holder for this preprint (which was not certified by peer review) is the author/funder, who has granted medRxiv a license to display the preprint in perpetuity. It is made available under a CC-BY-NC 4.0 International license.

respectively (Feng, Luo, \& Krueger, 2015). In fact, norm violations share several features with frustration. Indeed, given that we implicitly expect that others will follow social norms (e.g., fairness/reward) (Bicchieri \& Chavez, 2010), norm violations (e.g., unfairness/frustration) act as a barrier to goal-directed behaviors. Additionally, both unexpected non-reward and norm violations elicit negative emotional responses. For instance, past researchers have found that receiving unfair monetary offers induce negative affect such as anger, sadness and feelings of being betrayed (Fatfouta, Meshi, Merk1, \& Heekeren, 2018; Gradin et al., 2015; Paz et al., 2017). Furthermore, it has been shown that negative emotional arousal (e.g., sadness, anger \& heightened skin conductance) further increases the risk of rejecting unfair offers (Harlé, Chang, van't Wout, \& Sanfey, 2012; Harlé \& Sanfey, 2007; C. Liu, Chai, \& Yu, 2016; Osumi \& Ohira, 2010; van't Wout, Chang, \& Sanfey, 2010). On neurobiological grounds, it has also been observed that the activation of the anterior insula (during unfair offers) may mediate the relationship between negative emotions (i.e. sadness) and rejection rates (Harlé et al., 2012). Thus, in line with Berkowitz assumptions (1989), these results suggest that propensity towards retaliatory behaviors may be increased when the frustrative event give rises to heightened negative emotional responses. However, in the neuroscientific literature, the neural mechanisms elicited during frustrative events are largely unknown. In fact, frustration processing (or nonreward processing) has often been blurred by the dichotomous reward-punishment categorization and its overutilization as a baseline condition in fMRI task contrasts. Nonetheless, it may hide a particular series of actions involving the interaction between both reward and punishment processes.

In the last decade, frustration has been thought to be implicated in several psychopathologies that are at risk for aggressive behaviors (e.g., irritability, CD/ASPD, see 
medRxiv preprint doi: https://doi.org/10.1101/2021.05.12.21257119; this version posted May 19, 2021. The copyright holder for this preprint (which was not certified by peer review) is the author/funder, who has granted medRxiv a license to display the preprint in perpetuity.

It is made available under a CC-BY-NC 4.0 International license .

(Bertsch, Florange, \& Herpertz, 2020; Blair, 2010b; Harenski \& Kiehl, 2010; Leibenluft, 2017)).

Therefore, uncovering the neural bases of frustration processing is of great importance for our understanding of processes by which aggressive behaviors may likely arise. However, past metaanalyses did not produce reliable neurobiological markers of aggressive behaviors, potentially due to a substantial heterogeneity in the definition of aggression-related emotion and behavioral responses. For instance, a meta-analysis of fMRI studies on "state anger" (Puiu et al., 2020), which included a wide range of fMRI task contrasts (e.g., punishing others, rejecting unfair offers, retaliatory behaviors and passively reacting to provocation), revealed significant activations in the mPFC, pregenual ACC and right anterior insula. Similarly, another metaanalysis was conducted on "trait aggression" which included a variety of different tasks (e.g., theory of mind, passive viewing, working memory, probabilistic reversal task) with distinct psychiatric populations (e.g., schizophrenia, intermittent explosive disorder, antisocial personality disorder) and showed that only the precuneus emerged as significant cluster (Wong et al., 2019). The authors carried out an additional meta-analysis on "elicited aggression", which was more precisely defined (e.g., Taylor aggression paradigm and Violent first-person shooter games), and the meta-analysis yielded activations in the postcentral gyrus (Wong et al., 2019). Finally, in a recent meta-analysis on "anger experience", the authors have included heterogeneous fMRI task domains including retaliatory behaviors, social exclusion and anger imagery (Sorella, Grecucci, Piretti, \& Job, 2021), revealing activations in bilateral insula/vlPFC. Despite that these major differences in definition may partially explain the discrepancies in brain regions, it nonetheless illustrates the importance of dissecting homogeneous constructs using theory-driven terminology. 
medRxiv preprint doi: https://doi.org/10.1101/2021.05.12.21257119; this version posted May 19, 2021. The copyright holder for this preprint (which was not certified by peer review) is the author/funder, who has granted medRxiv a license to display the preprint in perpetuity.

It is made available under a CC-BY-NC 4.0 International license .

Based on a literature review, Blair (2016) has suggested that impulsive aggression may involve interactions between acute threat response (i.e., amygdala, hypothalamus and periaqueductal gray [PAG]), the vmPFC and the mid-cingulo-insular network (i.e., dACC, aMCC/pre-SMA and bilateral fronto-insular cortex). The current study therefore aims to unveilthe neural bases of the frustration-aggression theory and provide meta-analytical support for a neurobiological model of frustration-based impulsive aggression. More precisely, we sought to examine to what extent the frustrative non-reward and retaliatory behaviors spatially overlapped altogether, in order to provide a model of how this series of actions operate at the neurobiological level.

\section{Methods}

\subsection{Data Inclusion}

In the current meta-analysis, the search strategies were the BrainMap Database as well as the reference lists of recent meta-analyses (See Figure 1). Inclusion criteria were the use of whole-brain analyses in healthy controls reported in a standard reference space (Talairach/Tournoux, Montreal Neurological Institute [MNI]) using functional Magnetic Resonance Imaging (fMRI) or Positron Emission Tomography. Talairach coordinates were converted into MNI space before using them in analyses.

Frustrative events were defined as the withholding or the removal of an expect reward by others that was not performance-contingent (e.g., rewarded response inhibition tasks). Experiments involving frustrative events were retrieved by screening the BrainMap Database (i.e., Reward Paradigm Class and Normal Mapping Context as search terms which allowed to retrieve191 papers). Another search was done by screening references from recent meta-analyses 
medRxiv preprint doi: https://doi.org/10.1101/2021.05.12.21257119; this version posted May 19, 2021. The copyright holder for this preprint (which was not certified by peer review) is the author/funder, who has granted medRxiv a license to display the preprint in perpetuity.

It is made available under a CC-BY-NC 4.0 International license .

on reward/punishment processing (Dugré et al., 2018; Fouragnan, Retzler, \& Philiastides, 2018; Oldham et al., 2018). For the two-player games, we extracted data from the reference lists of recent meta-analyses on the Ultimatum Game (Bellucci, Camilleri, Iyengar, Eickhoff, \& Krueger, 2020; Feng et al., 2019). For the frustration meta-analysis, we pooled data from the one-player (e.g., Non-Reward Outcome in the Reward trial of the Monetary Incentive Delay Task) and two-player games (i.e., Unfair condition of the Ultimatum game), resulting in $\left(\right.$ Frustration $_{\text {SINGLE }}+$ Unfair $\left._{\text {MULTI }}\right)$ versus (Reward SINGLE $_{\text {Fair }}$ MULTI $)$. Indeed, this was done since frustration and unfairness shares a number of similarities. For instance, receiving a fair offer from the proposer results in a reward for both parties, in the Ultimatum Game. However, since the receiver implicitly expects the proposer to follow social norms about fairness (Bicchieri \& Chavez, 2010), violating this norm yields a non-rewarding outcome for the receiver (i.e., frustrative context).

Finally, the search for experiments on retaliatory behaviors was done by screening the reference lists of recent meta-analyses on aggressivity/anger (Puiu et al., 2020; Sorella et al., 2021; Wong et al., 2019). Experiments on retaliatory behaviors were defined by an explicit decision to punish another player that had provoked the participant (e.g., removing points, delivering a shock/noise).

- $\quad$ Insert Figure 1 About Here -

\subsection{Activation Likelihood Estimate method}

Experiments' coordinates were used for spatial convergence using the Activation Likelihood Estimate method (GingerALE version 3.0.2, (Eickhoff, Bzdok, Laird, Kurth, \& Fox, 2012; Eickhoff et al., 2009); http://www.brainmap.org/ale/). For each experiment, a 3D gaussian 
medRxiv preprint doi: https://doi.org/10.1101/2021.05.12.21257119; this version posted May 19, 2021. The copyright holder for this preprint (which was not certified by peer review) is the author/funder, who has granted medRxiv a license to display the preprint in perpetuity.

It is made available under a CC-BY-NC 4.0 International license .

probability distribution was modelled around each coordinate foci, weighted by the number of subjects in the experiment. This method is performed to account for spatial uncertainty due to template and between-subject variance (Eickhoff et al., 2012; Eickhoff et al., 2009). It also ensures that multiple coordinates from a single experiment does not jointly influence the modeled activation value of a single voxel. The probabilities of all activation foci in an experiment were then combined. Voxel-wise ALE scores arise from the union across all these experiment maps. Consequently, a cluster-level corrected threshold was applied on the voxelwise image. The size of the supra-threshold clusters was compared against a null distribution of cluster sizes derived from simulation of datasets. We used the following statistical threshold: $\mathrm{p}<0.001$ at voxel-level and FWE-p $<0.05$ at a cluster-level with 5000 permutations. Results were also reported using a more liberal statistical threshold of $\mathrm{p}<0.001$ uncorrected given that activation of subcortical regions during tasks eliciting emotional response may be suppressed by regulatory mechanisms in healthy subjects. Indeed, as hypothesized by Blair (2016), subcortical and midbrain regions including the amygdala, hypothalamus and PAG would be observed.

Conjunction analyses were carried out to examine spatial overlap between the metaanalytical maps. Here, test for convergence was determined by the intersection between the meta-analyses. These results are reported for a $\mathrm{p}<0.0001$ using 10,000 permutations.

\section{Results}

\subsection{Main Effects of Frustration-Aggression Phases}

\subsubsection{Frustration Processing}

The meta-analysis of main effect of frustration (non-reward) comprised 68 experiments (515 foci, 1801 subjects). ALE meta-analysis revealed significant activations in bilateral fronto- 
medRxiv preprint doi: https://doi.org/10.1101/2021.05.12.21257119; this version posted May 19, 2021. The copyright holder for this preprint (which was not certified by peer review) is the author/funder, who has granted medRxiv a license to display the preprint in perpetuity.

It is made available under a CC-BY-NC 4.0 International license.

insular cortex (FIC) and dACC/aMCC \& pre-SMA (see Table 2; Figure 2). Furthermore, when using a more liberal statistical threshold ( $\mathrm{p}<0.001$ uncorrected), we observed activation in the dmPFC, medial dorsal nucleus of the thalamus, the amygdala and the periaqueductal grey (PAG) (see Table 2; Figure 2A). Contrasting Frustration SINGLE versus Unfair $_{\text {MULTI }}$ showed differences only in a small cluster of the pre-SMA (See Supplementary Material)

Additionally, the reverse contrast examining the decreased activations after being frustrated (63 experiments, 395 foci and 3047 subjects) showed significant peak convergence in the ventral striatum (bilateral), medial OFC/vmPFC and the PCC/Precuneus (see Table 1; Figure

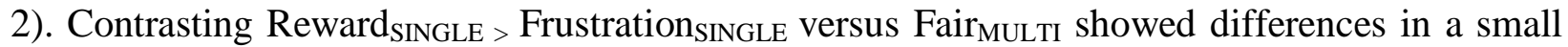
cluster encompassing the right putamen (See Supplementary Material).

- $\quad$ Insert Table 2 About Here -

\subsubsection{Retaliatory Behaviors}

Forty-two neuroimaging experiments were included in the ALE meta-analysis on retaliation (605 foci, 1285 subjects). Retaliatory behaviors were associated with activations in bilateral FIC, the dorsal striatum (i.e., caudate), the left postcentral gyrus/Inferior Parietal Lobule and the aMCC/pre-SMA (see Table 2; Figure 2). Using a more liberal threshold $(\mathrm{p}<0.001$ uncorrected), additional cluster in the PAG and the ventral posterolateral thalamus were observed.

- $\quad$ Insert Figure 2 About Here -

\subsection{Conjunction Analyses}


medRxiv preprint doi: https://doi.org/10.1101/2021.05.12.21257119; this version posted May 19, 2021. The copyright holder for this preprint (which was not certified by peer review) is the author/funder, who has granted medRxiv a license to display the preprint in perpetuity.

It is made available under a CC-BY-NC 4.0 International license .

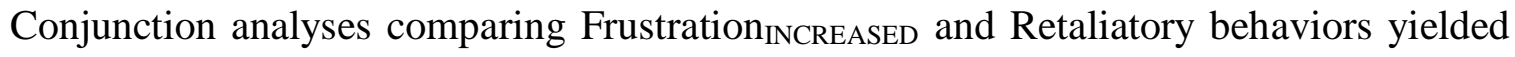
overlap in bilateral FIC (Left: $x=-32, y=20, z=-8, A L E=0.0255,224$ voxels; Right: $x=32, y=20$, $\mathrm{z}=2, \mathrm{ALE}=0.0312,204$ voxels $)$ as well as in the aMCC/pre-SMA $(\mathrm{x}=-4, \mathrm{y}=16, \mathrm{z}=50$, $\mathrm{ALE}=0.0255,98$ voxels) (See Figure 2). No significant spatial overlap was observed between the Frustration $_{\text {DECREASED }}$ and Retaliatory behaviors.

\section{Discussion}

The current study aimed to examine, through a meta-analysis, the neural bases of the core components of the frustration-aggression theory. Using a theory-driven definition of aggressionrelated constructs, this study also aimed to clarify the discrepancies in recent meta-analyses on anger/aggression and focus on uncovering processes which may increase the risk for reactive aggression. For instance, we observed that frustrative events yield decreased activations in the ventral striatum, medial $\mathrm{OFC}$ and $\mathrm{PCC} /$ precuneus while they activate bilateral fronto-insular regions (vlPFC, aINS, 1OFC) and aMCC/pre-SMA. We also observed that frustration was associated with increased activations of the dmPFC, thalamus, amygdala and PAG when using a more liberal statistical threshold. Additionally, retaliatory behaviors were associated with bilateral FIC, aMCC/pre-SMA as well as dorsal striatum and the primary somatosensory cortex (S1) as well as the PAG and thalamus only when using a more liberal threshold. Finally, conjunction analyses revealed that bilateral FIC may be common to frustration context and retaliatory behaviors. Results from this meta-analysis are of great significance as they provide empirical support for Blair's theoretical framework of impulsive aggression (Blair, 2016), emphasizing the primary role of vmPFC, dACC/aMCC (referred to dmPFC in Blair, (2016), anterior insula, amygdala and PAG in reactive aggression. We also observed that the FrustrationAggression network may involve other brain regions that have been neglected thus far, such as 
medRxiv preprint doi: https://doi.org/10.1101/2021.05.12.21257119; this version posted May 19, 2021. The copyright holder for this preprint (which was not certified by peer review) is the author/funder, who has granted medRxiv a license to display the preprint in perpetuity.

It is made available under a CC-BY-NC 4.0 International license .

the thalamus, caudate nucleus and SI. More importantly, our results provide additional insights about the potential mechanism underlying frustration-based impulsive aggression (See Figure 3).

\subsection{Integrative Neurobiological Model of Frustration-Aggression sequence}

Responding adequately to frustrative events is thought to be an evolutionary function which is necessary for species survival. For instance, aggressive behaviors may be appropriate to defend, protect or punish others from stealing community's food. Hence, aggressive behaviors which resulted from the omission of an expected reward have been observed in a variety of species such as in rodents (Burokas, Gutiérrez $\square$ Cuesta, Martín $\square$ García, \& Maldonado, 2012; de Almeida \& Miczek, 2002; Gallup, 1965), pigs (Arnone \& Dantzer, 1980; Dantzer, Arnone, \& Mormede, 1980), fishes (Vindas et al., 2012; Vindas et al., 2014) as well as in birds (Azrin, Hutchinson, \& Hake, 1966; Duncan \& Wood-Gush, 1971). To our knowledge, the current metaanalysis is the first to specifically examine the neural bases of frustrative-aggression sequence. In this meta-analysis, we followed Berkowitz' (1989) proposition suggesting that withholding/removing an expected reward would enhance emotional arousal, which further increase the risk for reactive aggression. Given that several psychopathologies may exhibit enhanced risk for frustration and reactive aggression (Bertsch et al., 2020; Leibenluft, 2017), its implication for clinical population are also discussed.

\subsubsection{The Activation and Deactivation systems underlying Frustration}

Evidence from the current meta-analysis suggests that two processes may co-occur when a reward has been frustrated. First, we found that withholding an expected reward results in significant decreased activations of the $\mathrm{VS}, \mathrm{vmPFC} / \mathrm{mOFC}$ and the vPCC. Interestingly, research 
medRxiv preprint doi: https://doi.org/10.1101/2021.05.12.21257119; this version posted May 19, 2021. The copyright holder for this preprint (which was not certified by peer review) is the author/funder, who has granted medRxiv a license to display the preprint in perpetuity. It is made available under a CC-BY-NC 4.0 International license .

has consistently shown that the ventral striatum (Abler, Erk, \& Walter, 2007; Abler, Walter, \& Erk, 2005; Bjork, Chen, Smith, \& Hommer, 2010; Bjork, Smith, \& Hommer, 2008; V. B. Gradin et al., 2013; McClure, Berns, \& Montague, 2003; Pessiglione, Seymour, Flandin, Dolan, \& Frith, 2006) and the vmPFC/mOFC (Bjork et al., 2004; Bjork et al., 2008; Knutson, Fong, Adams, Varner, \& Hommer, 2001; Knutson, Fong, Bennett, Adams, \& Hommer, 2003) actually deactivate in frustrative events. In addition, evidence functional and structural MRI studies has shown strong connectivity between the vmPFC and VS (Cauda et al., 2011; Di Martino et al., 2008; Hart, Leung, \& Balleine, 2014) which subserve goal-directed learning (Hart et al., 2014), supporting their frequent co-activation in meta-analyses on reward processing (Bartra et al., 2013; Liu et al., 2011; Oldham et al., 2018). However, results from past meta-analyses suggest that activation vPCC may be specific to reward processing (Bartra et al., 2013; Liu et al., 2011; Oldham et al., 2018), and may not be activated when receiving punishment (Dugré et al., 2018). Hence, there is currently no evidence of vPCC deactivation during unexpected non-reward, indicating potential artefactual results due to task-contrast (reward > unexpected non-reward).

Besides this deactivation system, we also found increased activation in bilateral anterior FIC as well as the dACC/aMCC and pre-SMA. Indeed, functional characterization analyses revealed their strong relationship with attention, reasoning, reward, memory, inhibition and pain. These brain regions are crucial nodes of the midcingulo-insular network (Uddin, Yeo, \& Spreng, 2019) which is mainly involved in detection of salient information in the environment (i.e., stimulus-driven attention). The co-occurrence of the aMCC/pre-SMA and anterior FIC has also been noticed a wide range of regulatory mechanisms such as conflict monitoring and emotion regulation strategies (Buhle et al., 2014; Morawetz, Bode, Derntl, \& Heekeren, 2017) and response to surprising salient outcome (Fouragnan et al., 2018). More specifically, it has been 
medRxiv preprint doi: https://doi.org/10.1101/2021.05.12.21257119; this version posted May 19, 2021. The copyright holder for this preprint (which was not certified by peer review) is the author/funder, who has granted medRxiv a license to display the preprint in perpetuity. It is made available under a CC-BY-NC 4.0 International license.

suggested that the anterior insula may play a major role in emotional awareness by integrating interoceptive prediction errors with and top-down signals originating from the aMCC/pre-SMA and PFC (Gu, Hof, Friston, \& Fan, 2013). Hence, findings from our meta-analysis highlight the role of the midcingulo-insular regions in frustrative non-reward.

Moreover, we observed significant activation of the dmPFC, medial dorsal thalamus, amygdala and PAG when using a more liberal statistical threshold ( $\mathrm{p}<0.001$ uncorrected). These brain regions were further characterized as being involved in negative emotions (i.e., fear, sadness, anger, disgust), attention, explicit memory but also in happiness and reward. Relationships between these cortical (i.e., aMCC/pre-SMA, FIC and dmPFC) and subcortical structures (i.e., amygdala, thalamus, PAG) has often been reported in threat conditioning (Fullana et al., 2016; Mechias, Etkin, \& Kalisch, 2010), physiological arousal ((Hartley \& Phelps, 2010) for meta-analysis see (Beissner, Meissner, Bär, \& Napadow, 2013). The amygdala is involved in affective-motivational component of pain processing, while the PAG is known for playing a key role endogenous pain modulation and stress-induced analgesia (Ong, Stohler, \& Herr, 2019; Tanasescu, Cottam, Condon, Tench, \& Auer, 2016). In addition, past meta-analyses and studies suggested that the PAG may play a non-negligeable role in processing negative affect given its activation, not only in pain conditions, but also when viewing negative emotional pictures (Buhle et al., 2013; Kober et al., 2008; Wager et al., 2008). Hence, as proposed by Blair (Blair, 2016), these brain regions (acute threat system) may play a crucial role in heightening emotional responsiveness to the frustrative event, further mediating impulsive aggression.

Neurobiological markers of frustrative events may thus be characterized by interaction between these 3 subsystems. Evidence from structural and functional connectivity studies suggests that the ventral part of the anterior insula demonstrate close connections with the VS, 
medRxiv preprint doi: https://doi.org/10.1101/2021.05.12.21257119; this version posted May 19, 2021. The copyright holder for this preprint (which was not certified by peer review) is the author/funder, who has granted medRxiv a license to display the preprint in perpetuity. It is made available under a CC-BY-NC 4.0 International license .

amygdala and hypothalamus and dmPFC (to a lesser extent), whereas the dorsal part is rather connected with frontal pole, dACC and the aMCC/pre-SMA, which are subserving cognitive control processes (Deen, Pitskel, \& Pelphrey, 2011; Ghaziri et al., 2018; Menon et al., 2020; Nomi et al., 2016). Indeed, the IMAGEN Consortium $(n=1510)$ has shown that when rewards were unexpectedly omitted, the ventral striatum was negatively correlated with activity of the insular cortex (bilaterally), the aMCC/pre-SMA and the thalamus (Cao et al., 2019). Interestingly, similar negative relationship has also been observed in pain studies showing deactivation of the VS (Aharon, Becerraa, Chabris, \& Borsooka, 2006; Becerra \& Borsook, 2008; Becerra, Navratilova, Porreca, \& Borsook, 2013) and increased activation of aMCC/preSMA and insular cortex during pain onset (Meta-analyses: (Duerden \& Albanese, 2013; Friebel, Eickhoff, \& Lotze, 2011; Jensen et al., 2016; Lanz, Seifert, \& Maihöfner, 2011; Tanasescu et al., 2016; $\mathrm{Xu}$ et al., 2020). The negative associations are consistent with the pattern of activations and de-activations observed in the current meta-analysis. Considering these, the ventral aINS may thus receive VS signals, enabling the threat system through its projection to the amygdala and hypothalamus when perceiving non-reward as a personal threat. Co-occurrently, projections from the dorsal part of the aINS to the aMCC/pre-SMA may reflect attentional shift towards the source of blockage (salient stimuli).

Furthermore, deactivation of the vmPFC may also play a prominent role in frustrative non-reward. Indeed, it has been shown that the vmPFC has a multifaceted role in emotional responding given its connectivity with both VS (reward) and Amygdala (threat) (Haber, 2016; Haber \& Knutson, 2010; Hiser \& Koenigs, 2018; Schneider \& Koenigs, 2017). Indeed, vmPFC has been linked with subjective valuation and probability of reward (Bartra et al., 2013). Lesions studies have shown that the vmPFC is crucial for reinforcement-based decision making (Fellows 
medRxiv preprint doi: https://doi.org/10.1101/2021.05.12.21257119; this version posted May 19, 2021. The copyright holder for this preprint (which was not certified by peer review) is the author/funder, who has granted medRxiv a license to display the preprint in perpetuity. It is made available under a CC-BY-NC 4.0 International license.

\& Farah, 2007; Koenigs, Kruepke, \& Newman, 2010; Schneider \& Koenigs, 2017) and is associated with increased appetite for risky decision-making (hot decisions)(Clark et al., 2008; Spaniol, Di Muro, \& Ciaramelli, 2019; Studer, Manes, Humphreys, Robbins, \& Clark, 2015). Thus, blocking a subjectively salient reward may deactivate the vmPFC, and alter subsequent decision-making in affect-rich contexts. This concurs with frustration theories proposing that the subjective value of rewards may explain interindividual difference in emotional arousal after a frustrating event (Berkowitz, 1989; Breuer \& Elson). For instance, participants receiving anodal stimulation of the vmPFC perceived unfair offers as fairer than those in the sham group (Gilam et al., 2018), which indicates that stimulation of the vmPFC may modulate subjective value toward a given stimulus and further decrease the need for regulating (dACC/FIC) brain regions involved in the acute threat system (amygdala, thalamus, PAG). The vmPFC is also thought to play a role in generating and suppressing affect by a top-down regulating process in which the vmPFC may serves as a brake to inhibit the amygdala and the PAG and adapt behavior when evaluating imminence of the threat (Hiser \& Koenigs, 2018; Kim et al., 2011; Mobbs et al., 2007). Nevertheless, frustrative non-reward may be characterized by deactivation of the vmPFC and VS, which enable stimulus-driven attention (aMCC/pre-SMA and FIC) and disinhibit the acute threat system, induces vigilance and physiological arousal.

- $\quad$ Insert Figure 3 About Here -

\subsubsection{Neural bases of Retaliatory Behaviors}

In the past decades, researchers have attempted to model the core neural features of reactive aggression. For instance, it has been argued that the medial hypothalamus, amygdala and the PAG are crucial nodes for understanding retaliatory behaviors (Bertsch et al., 2020; Blair, 
medRxiv preprint doi: https://doi.org/10.1101/2021.05.12.21257119; this version posted May 19, 2021. The copyright holder for this preprint (which was not certified by peer review) is the author/funder, who has granted medRxiv a license to display the preprint in perpetuity. It is made available under a CC-BY-NC 4.0 International license .

2016; Crowe \& Blair, 2008; Gregg \& Siegel, 2001; Lickley \& Sebastian, 2018; Panksepp, 2004; Panksepp \& Zellner, 2004). In our meta-analysis we found that retaliatory behaviors were mainly characterized by activation in the dorsal striatum and primary somatosensory cortex (SI, BA3 encompassing the hand network of the left hemisphere), as well as bilateral FIC and aMCC/preSMA. Through projections from these regions to the caudate nucleus ((Haber, 2016; Haber \& Knutson, 2010; Leh, Ptito, Chakravarty, \& Strafella, 2007; Xiaojin Liu et al., 2021), behavioral responses to frustration are likely to arise. Indeed, the dorsal striatum has been implicated in several goal-directed decision making and action selection and initiation (Balleine, Delgado, \& Hikosaka, 2007; Haber \& Knutson, 2010; O'Doherty et al., 2004). Additionally, lesions to dorsal striatum produce deficient defensive behaviors in rats (Kirkby \& Kimble, 1968; Winocur, 1974), supporting the role of action preparation and motor control in fight-or-flight response. Thus, this result is somewhat expected given that paradigms used in humans to investigate retaliatory behaviors often involve decisions whereby participants select the severity of the punishment directed towards others. However, some authors suggests that the VS may be implicated in retaliatory behaviors through a mechanism involving pleasure to retaliate (Chester \& DeWall, 2016, 2018). In this meta-analysis, we did not find any spatial convergence in VS and other brain regions involved in the reward system, indicating that retaliatory behaviors in healthy subjects may not be as "pleasurable" as previously expected. Nevertheless, we cannot rule out the possibility that the VS activation during retaliation (or when viewing others in pain) may be specific to some clinical populations such as CP/ASPD with psychopathic traits and/or high levels of sadistic traits (Decety, Chen, Harenski, \& Kiehl, 2013; Decety, Michalska, Akitsuki, \& Lahey, 2009; Harenski, Thornton, Harenski, Decety, \& Kiehl, 2012; Perino, Moreira, \& Telzer, 2019). Further research is needed to examine this possibility. 
medRxiv preprint doi: https://doi.org/10.1101/2021.05.12.21257119; this version posted May 19, 2021. The copyright holder for this preprint (which was not certified by peer review) is the author/funder, who has granted medRxiv a license to display the preprint in perpetuity. It is made available under a CC-BY-NC 4.0 International license .

Concerning the left SI this region has been consistently reported in meta-analyses on motor and tactile imagery (Hardwick, Caspers, Eickhoff, \& Swinnen, 2018; Hétu et al., 2013; McNorgan, 2012). Despite that the relationship between retaliatory behaviors and somatosensory cortex is not well understood, the activation of the SI raises the intriguing possibility that subjects may be inclined to mentally simulate aggressive behaviors (e.g., slapping, punching). Indeed, this presumption is supported by studies using script-driven imagery tasks of aggressive behaviors (Herpertz et al., 2017; Treadway et al., 2014). However, it should be noted that the SI is found to be significantly activated in some but not all meta-analyses on pain perception (Duerden \& Albanese, 2013; Friebel et al., 2011; Jensen et al., 2016; Lanz et al., 2011; Tanasescu et al., 2016; Xu et al., 2020), indicating that it may be involved in the sensorydiscriminative component of pain. Furthermore, it has been shown that the SI may also be involved when imaging oneself being in pain (Decety et al., 2013; Decety \& Porges, 2011; Lamm, Decety, \& Singer, 2011). These results nevertheless imply that the decision to retaliate involves an element of mentalization. Considering that current theoretical models on aggression have largely ignored the potential role of the primary somatosensory cortex, future studies should thus aim to clarify its precise role in retaliatory behaviors. In addition, we found that the thalamus and the PAG may also be involved retaliation, albeit observed when using a more liberal statistical threshold ( $\mathrm{p}<0.001$ uncorrected). More precisely, activation was seen ventral posterolateral part of the thalamus, compared to the medial dorsal cluster observed in frustration. Activation in this particular region sheds a new light on reactive aggression, since evidence indicates strong projections between the ventral posterolateral thalamus and the S1, which form an important hub in nociceptive pain (Ab Aziz \& Ahmad, 2006; Vierck, Whitsel, Favorov, Brown, \& Tommerdahl, 2013). As mentioned earlier, the PAG plays an important role in pain 
medRxiv preprint doi: https://doi.org/10.1101/2021.05.12.21257119; this version posted May 19, 2021. The copyright holder for this preprint (which was not certified by peer review) is the author/funder, who has granted medRxiv a license to display the preprint in perpetuity. It is made available under a CC-BY-NC 4.0 International license .

modulation (Ong et al., 2019; Tanasescu et al., 2016). Thus, activation of the PAG may modulate pain perception (i.e., thalamus, SI) to accurately prepare innate defensive behavior (action preparation: caudate nucleus) against the source of the blocked reward. Indeed, it has been shown that stimulation of the PAG activates defensive behaviors in rodents and cats, namely the fight-or-flight response (Bandler \& Depaulis, 1991; Deng, Xiao, \& Wang, 2016; Lovick, 1993). Interestingly, according to Panksepp theory ( 2004; Panksepp \& Zellner, 2004), the main hubs of the RAGE system primarily involve the PAG, the amygdala and the hypothalamus. Nearly a century ago, it has been observed that disrupting the diencephalon (hypothalamus and thalamus) and midbrain (PAG) from the cortex (and upper forebrain) produced rage-like behaviors in cats (Bard, 1934). However, it must be acknowledged that we did not observe any activation in the amygdala, which is a core brain region of the threat system. However, given that retaliation is a behavioral response following decisions that were made to punish/harm others in an emotionally intense context, we argue that the amygdala may not be directly involved in action preparation to harm others but may be rather implicated in the affective response to frustrative events, which further initiates defensive behavioral responses (reactive aggression) through PAG activation.

In sum, we found that frustrative non-reward and retaliatory behaviors are both characterized by bilateral FIC and aMCC/pre-SMA, which support Blair (2016)'s assumption on the role of these regions in reactive aggression. It is interesting to note that these brain regions are commonly activated in a wide range of fMRI tasks (Yarkoni, Poldrack, Nichols, Van Essen, \& Wager, 2011) such as those involving pain and empathy (Bzdok et al., 2012; Fallon, Roberts, \& Stancak, 2020; Fan, Duncan, de Greck, \& Northoff, 2011; Lamm et al., 2011). Indeed, both regions are core hubs of the ventral attention network, namely the salience network which subserve stimulus-driven attention (Uddin et al., 2019). Thus, their involvement in frustrative 
medRxiv preprint doi: https://doi.org/10.1101/2021.05.12.21257119; this version posted May 19, 2021. The copyright holder for this preprint (which was not certified by peer review) is the author/funder, who has granted medRxiv a license to display the preprint in perpetuity.

It is made available under a CC-BY-NC 4.0 International license .

non-reward and retaliation may indicate detection of salient and relevant stimuli in the environment (source of frustration) across these two contexts in order to adequately respond to it. Nevertheless, evidence suggests that lesions and transcranial stimulation of FIC regions are both associated with exaggerated emotional responses (Agustín-Pavón et al., 2012; Gallucci, Riva, Lauro, \& Bushman, 2020; Riva et al., 2017; Riva, Romero Lauro, DeWall, Chester, \& Bushman, 2015; Shiba, Kim, Santangelo, \& Roberts, 2015; Vergallito, Riva, Pisoni, \& Lauro, 2018). Taking together, we argue that FIC and aMCC/pre-SMA may be necessary in detecting salient stimuli and reorienting attention toward the source of frustration, further signalling emotional responses (Frustration). Thus, persistent attention towards this stimulus would thus be crucial for evaluating and initiating relevant behavioral responses to the frustrating object (Retaliation).

\subsection{Neurobiological evidence of the Frustration-Aggression model in clinical populations}

Exaggerated responses to frustration are often reported in several psychopathologies that are at risk for reactive aggression such as children and adolescents with high irritability ODD/CD and adult with BPD/ASPD (Bertsch et al., 2020; Blair, 2016; Leibenluft, 2017). Given the limited research on neurobiological correlates of frustration in clinical population, we nonetheless provide evidence that subjects at risk for reactive aggression may exhibit neural deficits within the frustration-aggression neurobiological model.

In response to expected reward that was frustrated, we showed three subsystems that are likely to be interconnected. For instance, as previously shown, deactivation of reward processing may be crucial in our understanding of neural responses to frustration. Interestingly, studies suggest that greater deactivation of the VS during reward omission was observed in adolescents with externalizing symptoms (Bjork et al., 2010) and adults with substance dependent patients 
medRxiv preprint doi: https://doi.org/10.1101/2021.05.12.21257119; this version posted May 19, 2021. The copyright holder for this preprint (which was not certified by peer review) is the author/funder, who has granted medRxiv a license to display the preprint in perpetuity. It is made available under a CC-BY-NC 4.0 International license .

which exhibited high levels of impulsivity and neuroticism (Bjork et al., 2008). Moreover, past research demonstrated deficits in expected value sensitivity within the vmPFC (greater deactivation) was observed in children with disruptive behavior disorders (DBDs) compared to typically developing children (White et al., 2013). Evidence also reveals greater vmPFC deactivation when anticipating non-rewards in adults with high psychopathic traits (Bjork, Chen, \& Hommer, 2012). However, given the mixed findings regarding deficits in reward processing among CP/ASPD subjects (Byrd, Loeber, \& Pardini, 2014; Dugré et al., 2020; Murray, Waller, \& Hyde, 2018), deactivation of the reward system during frustration requires further research. Nevertheless, extensive research supports the role of vmPFC in aggressive subjects. In our recent meta-analysis of resting-state connectivity studies, we observed that the vmPFC was a crucial disconnected hub in CP/ASPD subjects, which was also negatively associated with severity antisocial behaviors (Dugré \& Potvin, 2021). Furthermore, lesions (or inactivation) of the $\mathrm{OFC} / \mathrm{vmPFC}$ are frequently linked with greater emotional reactivity and impulsive aggression (Agustín-Pavón et al., 2012; Berlin, Rolls, \& Kischka, 2004; H. A. Berlin, Rolls, \& Iversen, 2005; Izquierdo, Suda, \& Murray, 2005; Kuniishi et al., 2017; Shiba et al., 2015) likely through a disrupted connectivity with the amygdala (Motzkin, Philippi, Wolf, Baskaya, \& Koenigs, 2015). Indeed, evidence strongly support the role of deficient vmPFC-amygdala connectivity as a main neurobiological marker of individuals at risk for aggression (Blair, 2008; Blair, 2016; Blair, 2007; Marsh et al., 2011; Marsh et al., 2008; Yoder, Harenski, Kiehl, \& Decety, 2015). Given that the deactivation of the vmPFC is frequently observed in patients with exaggerated emotional response (Grupe, Wielgosz, Davidson, \& Nitschke, 2016; Milad et al., 2009; VanElzakker, Staples-Bradley, \& Shin, 2018), we argue that a greater vmPFC deactivation in response to frustrative events may disinhibit the threat system which give rises to exaggerated emotional 
medRxiv preprint doi: https://doi.org/10.1101/2021.05.12.21257119; this version posted May 19, 2021. The copyright holder for this preprint (which was not certified by peer review) is the author/funder, who has granted medRxiv a license to display the preprint in perpetuity. It is made available under a CC-BY-NC 4.0 International license .

arousal, therefore requiring extensive regulation/control (FIC \& aMCC/pre-SMA) in healthy controls. In clinical populations at risk for reactive aggression, research indicates deficient regulatory mechanism when processing negative emotions (Coskunpinar, Dir, \& Cyders, 2013; Fairchild et al., 2019; Graziano \& Garcia, 2016; Hershberger, Um, \& Cyders, 2017; Kohls et al., 2020). For instance, adolescents with bipolar disorder exhibit deficits in vmPFC-FIC functional connectivity when processing feedback in a reward-frustrating task (Ross et al., 2020). Among subjects manifesting aggressive \& antisocial behaviors, deficits in dACC/aMCC \& FIC are frequently reported in meta-analyses of functional and structural neuroimaging studies (Alegria, Radua, \& Rubia, 2016; Dugré \& Potvin, 2021; Dugré et al., 2020; Poeppl et al., 2019; Rogers \& De Brito, 2016). More specifically, a recent meta-analysis demonstrated that the CP/ASPD subjects fail to activate these regions in response to threatening stimuli (Dugré et al., 2020), concurring with a recent study showing that hyperaggressive mice exhibited decreased activation of the ACC during confrontations (van Heukelum et al., 2021). Here, we provided evidence that clinical populations showed a wide range of neural deficits in brain regions involved in the Frustration-Aggression network which may increase their risk for reactive aggression. More precisely, deficits in the vmPFC may be considered as a neurobiological marker of this series of action given its connectivity with multiple brain regions spanning various systems including reward (VS), affective (amygdala, thalamus, PAG) and stimuli-driven attention (aMCC/preSMA \& FIC). We further suggest that prominent hypofunction of the aMCC/pre-SMA and FIC in clinical populations may yield in persistent emotional response (anger) towards the source of frustration, therefore increasing substantially the risk for retaliatory behaviors.

Finally, it has been proposed that the threat system (i.e., amygdala, PAG, hypothalamus) may be largely implicated in reactive aggression (Bertsch et al., 2020; Blair, 2016; Crowe \& 
medRxiv preprint doi: https://doi.org/10.1101/2021.05.12.21257119; this version posted May 19, 2021. The copyright holder for this preprint (which was not certified by peer review) is the author/funder, who has granted medRxiv a license to display the preprint in perpetuity. It is made available under a CC-BY-NC 4.0 International license .

Blair, 2008; Gregg \& Siegel, 2001; Lickley \& Sebastian, 2018; Panksepp, 2004; Panksepp \& Zellner, 2004). However, current models of frustration do not take into account the fact that subjects exhibiting antisocial behaviors generally show brain hypo-reactivity to threatening stimuli (Dugré et al., 2020) and are often characterized as being fearless (Barker, Oliver, Viding, Salekin, \& Maughan, 2011; Cote, Tremblay, Nagin, Zoccolillo, \& Vitaro, 2002; Frogner, Andershed, \& Andershed, 2018; Waller \& Wagner, 2019). In this sense, there is a hole in the literature examining how individuals at high risk for reactive aggression may perpetrate such behaviors if they are characterized as emotionally hyporeactive (Blair, 2010b; Harenski \& Kiehl, 2010). One explanation is that $\mathrm{CU}$ traits may mediate relationships between threatening stimuli and amygdala activity (Blair, Leibenluft, \& Pine, 2014; Hyde, Shaw, \& Hariri, 2013; Viding, Fontaine, \& McCrory, 2012). However, in a recent meta-analysis, Dugré and colleagues (2020) found that the severity of antisocial behaviors was negatively associated with the activity in the amygdala (even after controlling for severity of $\mathrm{CU}$ traits), whereas no evidence of such relationship was observed with CU traits across whole-brain studies. Indeed, CU traits were only related to the activity of the amygdala in studies using predefined region-of-interest (Dugré et al., 2020). Interestingly, although predominantly associated with increased risk for proactive aggression, psychopathic individuals also exhibit reactive aggression (Cima \& Raine, 2009; Fanti, Frick, \& Georgiou, 2009; Fite, Stoppelbein, \& Greening, 2009; Reidy, Shelley-Tremblay, \& Lilienfeld, 2011). Thus, how would they display reactive aggression if they are mainly characterized by emotional underreponsiveness to threat. Therefore, one possibility that could explain such paradoxical results is that CP/ASPD subjects may need more subjectively salient stimuli to enable hyper-activity of the "usually underresponsive" acute threat system. In this sense, the hypo-reactivity observed in CP/ASPD cannot be generalized to every context. Indeed, 
medRxiv preprint doi: https://doi.org/10.1101/2021.05.12.21257119; this version posted May 19, 2021. The copyright holder for this preprint (which was not certified by peer review) is the author/funder, who has granted medRxiv a license to display the preprint in perpetuity.

It is made available under a CC-BY-NC 4.0 International license .

given that this population is often described as exhibiting selfish behaviors (Krupp, Sewall, Lalumière, Sheriff, \& Harris, 2012), we cannot rule out the possibility that CP/ASPD subjects may rather exhibit emotional hyperarousal in some particular contexts such as when the pursuit of their goals has been interrupted (Blair, 2010a). For instance, blocking an expected reward that is subjectively valuable may be more salient than usual emotional stimuli (e.g., facial expression), therefore enhancing the emotional response as well as the risk for reactive aggression. It is thus unequivocal that there is a crucial need to examine this assumption with novel fMRI tasks that specifically target frustration.

\section{Limitations}

The current meta-analysis is the first to examine the neural mechanisms involved in frustration as defined as the omission of an expected reward as well as to investigate the commonalities in the neural processes involved in frustration and retaliatory behaviors. However, some limitations of this meta-analysis should be noted. First, we sought to examine the series of actions underlying the frustration-aggression theory through a multi-domain metaanalysis. Hence, through conjunction analyses, we assumed the temporal sequences between both events, given that it was not possible to test directly this series of actions and how they influence one another. Second, several factors may mediate the relationship between frustrative events and negative affect such as the goal significance and expectations, but also the repeated frustration or sustained effort (Berkowitz, 1989; Breuer \& Elson, 2017). Thus, these factors may partially explain why we observed activation in the threat response system (e.g., amygdala, thalamus, PAG) only when we lowered the statistical threshold ( $\mathrm{p}<0.001$ uncorrected) (Yu, Mobbs, Seymour, Rowe, \& Calder, 2014). Finally, for most studies, retaliatory behaviors were 
medRxiv preprint doi: https://doi.org/10.1101/2021.05.12.21257119; this version posted May 19, 2021. The copyright holder for this preprint (which was not certified by peer review) is the author/funder, who has granted medRxiv a license to display the preprint in perpetuity.

It is made available under a CC-BY-NC 4.0 International license .

defined by a condition in which subjects decided the severity of the punishment (noise or points removed). Thus, inter-individual differences in retaliatory behaviors remains unknown (e.g., overt/covert, physical/verbal). Future studies may strive to develop functional neuroimaging tasks, with ecological validity, that specifically examine the interactions between frustration and reactive aggression, and how the level of frustration may influence retaliatory behavior. In these investigations, careful attention will need to be paid to the roles of the aINS and the aMCC. At the methodological level, it will be important to select fMRI acquisition parameters optimized to detect activations in brain regions such the amygdala and the PAG.

\section{Conclusions}

In the current study, we sought to examine the neural complexity of frustration as an inhibiting context (e.g., non-reward processing) rather than merely an emotional response. Following the definition provided by the Frustration-Aggression theory (Berkowitz, 1989), we found that withholding an expected reward is mainly characterized by deactivation of the reward system and activation of brain regions involved in the Midcingulo-insular network and acute threat response. Additionally, spatial overlap between frustration and retaliatory behaviors were observed in bilateral FIC and aMCC/pre-SMA, but the latter also involved brain regions subserving goal-directed action preparation and somato-sensory processes. Thus, the current study provides a novel neurobiological framework of frustration-based impulsive aggression based on meta-analytical evidence. Future studies should aim to develop specific fMRI tasks that specifically target frustration-aggression theory to better understand reactive aggression in clinical populations. 
medRxiv preprint doi: https://doi.org/10.1101/2021.05.12.21257119; this version posted May 19, 2021. The copyright holder for this preprint (which was not certified by peer review) is the author/funder, who has granted medRxiv a license to display the preprint in perpetuity. It is made available under a CC-BY-NC 4.0 International license .

\section{Disclosures}

The authors declare no financial/personal interest or belief that could affect their objectivity.

\section{Acknowledgments}

JRD is holder of a scholarship from the Fonds de Recherche du Québec en Santé (FRQS). SP is holder of the Eli Lilly Canada Chair on Schizophrenia Research.

\section{REFERENCES}

Ab Aziz, C. B., \& Ahmad, A. H. (2006). The role of the thalamus in modulating pain. The Malaysian journal of medical sciences: MJMS, 13(2), 11.

Abler, B., Erk, S., \& Walter, H. (2007). Human reward system activation is modulated by a single dose of olanzapine in healthy subjects in an event-related, double-blind, placebocontrolled fMRI study. Psychopharmacology, 191(3), 823-833.

Abler, B., Walter, H., \& Erk, S. (2005). Neural correlates of frustration. Neuroreport, 16(7), 669672.

Agustín-Pavón, C., Braesicke, K., Shiba, Y., Santangelo, A. M., Mikheenko, Y., Cockroft, G., . . . Roberts, A. C. (2012). Lesions of ventrolateral prefrontal or anterior orbitofrontal cortex in primates heighten negative emotion. Biological psychiatry, 72(4), 266-272.

Aharon, I., Becerraa, L., Chabris, C., \& Borsooka, D. (2006). Noxious heat induces fMRI activation in two anatomically distinct clusters within the nucleus accumbens. Neuroscience letters, 392(3), 159-164.

Alegria, A. A., Radua, J., \& Rubia, K. (2016). Meta-analysis of fMRI studies of disruptive behavior disorders. American Journal of Psychiatry, 173(11), 1119-1130.

Arnone, M., \& Dantzer, R. (1980). Does frustration induce aggression in pigs? Applied Animal Ethology.

Azrin, N., Hutchinson, R. R., \& Hake, D. (1966). EXTINCTION $\square$ INDUCED AGGRESSION 1. Journal of the Experimental Analysis of behavior, 9(3), 191-204.

Balleine, B. W., Delgado, M. R., \& Hikosaka, O. (2007). The role of the dorsal striatum in reward and decision-making. Journal of Neuroscience, 27(31), 8161-8165.

Bandler, R., \& Depaulis, A. (1991). Midbrain periaqueductal gray control of defensive behavior in the cat and the rat. In The midbrain periaqueductal gray matter (pp. 175-198): Springer.

Bard, P. (1934). On emotional expression after decortication with some remarks on certain theoretical views: Part II. Psychological review, 41(5), 424. 
medRxiv preprint doi: https://doi.org/10.1101/2021.05.12.21257119; this version posted May 19, 2021. The copyright holder for this preprint

(which was not certified by peer review) is the author/funder, who has granted medRxiv a license to display the preprint in perpetuity. It is made available under a CC-BY-NC 4.0 International license .

Barker, E. D., Oliver, B. R., Viding, E., Salekin, R. T., \& Maughan, B. (2011). The impact of prenatal maternal risk, fearless temperament and early parenting on adolescent callous $\square$ unemotional traits: A 14 $\square$ year longitudinal investigation. Journal of Child Psychology and Psychiatry, 52(8), 878-888.

Bartra, O., McGuire, J. T., \& Kable, J. W. (2013). The valuation system: a coordinate-based meta-analysis of BOLD fMRI experiments examining neural correlates of subjective value. Neuroimage, 76, 412-427.

Becerra, L., \& Borsook, D. (2008). Signal valence in the nucleus accumbens to pain onset and offset. European journal of pain, 12(7), 866-869.

Becerra, L., Navratilova, E., Porreca, F., \& Borsook, D. (2013). Analogous responses in the nucleus accumbens and cingulate cortex to pain onset (aversion) and offset (relief) in rats and humans. Journal of neurophysiology, 110(5), 1221-1226.

Beissner, F., Meissner, K., Bär, K.-J., \& Napadow, V. (2013). The autonomic brain: an activation likelihood estimation meta-analysis for central processing of autonomic function. Journal of Neuroscience, 33(25), 10503-10511.

Bellucci, G., Camilleri, J. A., Iyengar, V., Eickhoff, S. B., \& Krueger, F. (2020). The emerging neuroscience of social punishment: meta-analytic evidence. Neuroscience \& Biobehavioral Reviews.

Berkowitz, L. (1989). Frustration-aggression hypothesis: examination and reformulation. Psychological bulletin, 106(1), 59.

Berlin, H., Rolls, E., \& Kischka, U. (2004). Impulsivity, time perception, emotion and reinforcement sensitivity in patients with orbitofrontal cortex lesions. Brain, 127(5), 1108-1126.

Berlin, H. A., Rolls, E. T., \& Iversen, S. D. (2005). Borderline personality disorder, impulsivity, and the orbitofrontal cortex. American Journal of Psychiatry, 162(12), 2360-2373.

Bertsch, K., Florange, J., \& Herpertz, S. C. (2020). Understanding brain mechanisms of reactive aggression. Current psychiatry reports, 22(12), 1-16.

Bicchieri, C., \& Chavez, A. (2010). Behaving as expected: Public information and fairness norms. Journal of Behavioral Decision Making, 23(2), 161-178.

Bjork, J. M., Chen, G., \& Hommer, D. W. (2012). Psychopathic tendencies and mesolimbic recruitment by cues for instrumental and passively obtained rewards. Biological psychology, 89(2), 408-415.

Bjork, J. M., Chen, G., Smith, A. R., \& Hommer, D. W. (2010). Incentive $\square$ elicited mesolimbic activation and externalizing symptomatology in adolescents. Journal of Child Psychology and Psychiatry, 51(7), 827-837.

Bjork, J. M., Knutson, B., Fong, G. W., Caggiano, D. M., Bennett, S. M., \& Hommer, D. W. (2004). Incentive-elicited brain activation in adolescents: similarities and differences from young adults. Journal of Neuroscience, 24(8), 1793-1802.

Bjork, J. M., Smith, A. R., \& Hommer, D. W. (2008). Striatal sensitivity to reward deliveries and omissions in substance dependent patients. Neuroimage, 42(4), 1609-1621.

Blair, R. (2008). The amygdala and ventromedial prefrontal cortex: functional contributions and dysfunction in psychopathy. Philosophical Transactions of the Royal Society B: Biological Sciences, 363(1503), 2557-2565.

Blair, R. (2010a). Psychopathy, frustration, and reactive aggression: the role of ventromedial prefrontal cortex. British journal of psychology, 101(3), 383-399. 
medRxiv preprint doi: https://doi.org/10.1101/2021.05.12.21257119; this version posted May 19, 2021. The copyright holder for this preprint

(which was not certified by peer review) is the author/funder, who has granted medRxiv a license to display the preprint in perpetuity. It is made available under a CC-BY-NC 4.0 International license .

Blair, R. (2010b). Reactive aggression and functional, not neural, specificity. British journal of psychology (London, England: 1953), 101(0 3), 407.

Blair, R. J. (2016). The neurobiology of impulsive aggression. Journal of child and adolescent psychopharmacology, 26(1), 4-9.

Blair, R. J. R. (2007). The amygdala and ventromedial prefrontal cortex in morality and psychopathy. Trends in cognitive sciences, 11(9), 387-392.

Blair, R. J. R., Leibenluft, E., \& Pine, D. S. (2014). Conduct disorder and callous-unemotional traits in youth. New England Journal of Medicine, 371(23), 2207-2216.

Breuer, J., \& Elson, M. Frustration-Aggression Theory. In The Wiley Handbook of Violence and Aggression (pp. 1-12).

Buhle, J. T., Kober, H., Ochsner, K. N., Mende-Siedlecki, P., Weber, J., Hughes, B. L., . . . Wager, T. D. (2013). Common representation of pain and negative emotion in the midbrain periaqueductal gray. Social cognitive and affective neuroscience, 8(6), 609-616.

Buhle, J. T., Silvers, J. A., Wager, T. D., Lopez, R., Onyemekwu, C., Kober, H., . . Ochsner, K. N. (2014). Cognitive reappraisal of emotion: a meta-analysis of human neuroimaging studies. Cerebral Cortex, 24(11), 2981-2990.

Burokas, A., Gutiérrez $\square$ Cuesta, J., Martín $\square$ García, E., \& Maldonado, R. (2012). Operant model of frustrated expected reward in mice. Addiction biology, 17(4), 770-782.

Byrd, A. L., Loeber, R., \& Pardini, D. A. (2014). Antisocial behavior, psychopathic features and abnormalities in reward and punishment processing in youth. Clinical Child and Family Psychology Review, 17(2), 125-156.

Bzdok, D., Schilbach, L., Vogeley, K., Schneider, K., Laird, A. R., Langner, R., \& Eickhoff, S. B. (2012). Parsing the neural correlates of moral cognition: ALE meta-analysis on morality, theory of mind, and empathy. Brain Structure and Function, 217(4), 783-796.

Cao, Z., Bennett, M., Orr, C., Icke, I., Banaschewski, T., Barker, G. J., . . Quinlan, E. B. (2019). Mapping adolescent reward anticipation, receipt, and prediction error during the monetary incentive delay task. Human brain mapping, 40(1), 262-283.

Cauda, F., Cavanna, A. E., D'agata, F., Sacco, K., Duca, S., \& Geminiani, G. C. (2011). Functional connectivity and coactivation of the nucleus accumbens: a combined functional connectivity and structure-based meta-analysis. Journal of Cognitive Neuroscience, 23(10), 2864-2877.

Chester, D. S., \& DeWall, C. N. (2016). The pleasure of revenge: retaliatory aggression arises from a neural imbalance toward reward. Social cognitive and affective neuroscience, 11(7), 1173-1182.

Chester, D. S., \& DeWall, C. N. (2018). Aggression is associated with greater subsequent alcohol consumption: A shared neural basis in the ventral striatum. Aggressive behavior, 44(3), 285-293.

Cima, M., \& Raine, A. (2009). Distinct characteristics of psychopathy relate to different subtypes of aggression. Personality and Individual Differences, 47(8), 835-840.

Clark, L., Bechara, A., Damasio, H., Aitken, M., Sahakian, B., \& Robbins, T. (2008). Differential effects of insular and ventromedial prefrontal cortex lesions on risky decision-making. Brain, 131(5), 1311-1322.

Coskunpinar, A., Dir, A. L., \& Cyders, M. A. (2013). Multidimensionality in impulsivity and alcohol use: A meta $\square$ analysis using the UPPS model of impulsivity. Alcoholism: Clinical and experimental research, 37(9), 1441-1450. 
medRxiv preprint doi: https://doi.org/10.1101/2021.05.12.21257119; this version posted May 19, 2021. The copyright holder for this preprint

(which was not certified by peer review) is the author/funder, who has granted medRxiv a license to display the preprint in perpetuity. It is made available under a CC-BY-NC 4.0 International license .

Cote, S., Tremblay, R. E., Nagin, D. S., Zoccolillo, M., \& Vitaro, F. (2002). Childhood behavioral profiles leading to adolescent conduct disorder: Risk trajectories for boys and girls. Journal of the American Academy of Child \& Adolescent Psychiatry, 41(9), 10861094.

Crowe, S. L., \& Blair, R. J. R. (2008). The development of antisocial behavior: What can we learn from functional neuroimaging studies? Development and psychopathology, 20(4), $1145-1159$.

Dantzer, R., Arnone, M., \& Mormede, P. (1980). Effects of frustration on behaviour and plasma corticosteroid levels in pigs. Physiology \& Behavior, 24(1), 1-4.

de Almeida, R. M., \& Miczek, K. A. (2002). Aggression escalated by social instigation or by discontinuation of reinforcement ("frustration") in mice: inhibition by anpirtoline: a 5HT1B receptor agonist. Neuropsychopharmacology, 27(2), 171-181.

Decety, J., Chen, C., Harenski, C., \& Kiehl, K. A. (2013). An fMRI study of affective perspective taking in individuals with psychopathy: imagining another in pain does not evoke empathy. Frontiers in Human Neuroscience, 7, 489.

Decety, J., Michalska, K. J., Akitsuki, Y., \& Lahey, B. B. (2009). Atypical empathic responses in adolescents with aggressive conduct disorder: a functional MRI investigation. Biological psychology, 80(2), 203-211.

Decety, J., \& Porges, E. C. (2011). Imagining being the agent of actions that carry different moral consequences: an fMRI study. Neuropsychologia, 49(11), 2994-3001.

Deen, B., Pitskel, N. B., \& Pelphrey, K. A. (2011). Three systems of insular functional connectivity identified with cluster analysis. Cerebral Cortex, 21(7), 1498-1506.

Deng, H., Xiao, X., \& Wang, Z. (2016). Periaqueductal gray neuronal activities underlie different aspects of defensive behaviors. Journal of Neuroscience, 36(29), 7580-7588.

Di Martino, A., Scheres, A., Margulies, D. S., Kelly, A., Uddin, L. Q., Shehzad, Z., . . Milham, M. P. (2008). Functional connectivity of human striatum: a resting state FMRI study. Cerebral Cortex, 18(12), 2735-2747.

Dollard, J., Miller, N. E., Doob, L. W., Mowrer, O. H., \& Sears, R. R. (1939). Frustration and aggression.

Duerden, E. G., \& Albanese, M. C. (2013). Localization of pain $\square$ related brain activation: A meta $\square$ analysis of neuroimaging data. Human brain mapping, 34(1), 109-149.

Dugré, J. R., Dumais, A., Bitar, N., \& Potvin, S. (2018). Loss anticipation and outcome during the Monetary Incentive Delay Task: a neuroimaging systematic review and metaanalysis. PeerJ, 6, e4749.

Dugré, J. R., \& Potvin, S. (2021). Impaired attentional and socio-affective networks in subjects with antisocial behaviors: a meta-analysis of resting-state functional connectivity studies. Psychological medicine, 1-11.

Dugré, J. R., Radua, J., Carignan-Allard, M., Dumais, A., Rubia, K., \& Potvin, S. (2020). Neurofunctional abnormalities in antisocial spectrum: A meta-analysis of fMRI studies on Five distinct neurocognitive research domains. Neuroscience \& Biobehavioral Reviews.

Duncan, I., \& Wood-Gush, D. (1971). Frustration and aggression in the domestic fowl. Animal Behaviour, 19(3), 500-504.

Eickhoff, S. B., Bzdok, D., Laird, A. R., Kurth, F., \& Fox, P. T. (2012). Activation likelihood estimation meta-analysis revisited. Neuroimage, 59(3), 2349-2361. 
medRxiv preprint doi: https://doi.org/10.1101/2021.05.12.21257119; this version posted May 19, 2021. The copyright holder for this preprint

(which was not certified by peer review) is the author/funder, who has granted medRxiv a license to display the preprint in perpetuity. It is made available under a CC-BY-NC 4.0 International license .

Eickhoff, S. B., Laird, A. R., Grefkes, C., Wang, L. E., Zilles, K., \& Fox, P. T. (2009). Coordinate $\square$ based activation likelihood estimation meta $\square$ analysis of neuroimaging data: A random $\square$ effects approach based on empirical estimates of spatial uncertainty. Human brain mapping, 30(9), 2907-2926.

Fairchild, G., Hawes, D. J., Frick, P. J., Copeland, W. E., Odgers, C. L., Franke, B., . . De Brito, S. A. (2019). Conduct disorder. Nature Reviews Disease Primers, 5(1), 1-25.

Fallon, N., Roberts, C., \& Stancak, A. (2020). Shared and distinct functional networks for empathy and pain processing: a systematic review and meta-analysis of fMRI studies. Social cognitive and affective neuroscience, 15(7), 709-723.

Fan, Y., Duncan, N. W., de Greck, M., \& Northoff, G. (2011). Is there a core neural network in empathy? An fMRI based quantitative meta-analysis. Neuroscience \& Biobehavioral Reviews, 35(3), 903-911.

Fanti, K. A., Frick, P. J., \& Georgiou, S. (2009). Linking callous-unemotional traits to instrumental and non-instrumental forms of aggression. Journal of Psychopathology and Behavioral Assessment, 31(4), 285.

Fatfouta, R., Meshi, D., Merkl, A., \& Heekeren, H. R. (2018). Accepting unfairness by a significant other is associated with reduced connectivity between medial prefrontal and dorsal anterior cingulate cortex. Social neuroscience, 13(1), 61-73.

Fellows, L. K., \& Farah, M. J. (2007). The role of ventromedial prefrontal cortex in decision making: judgment under uncertainty or judgment per se? Cerebral Cortex, 17(11), 26692674.

Feng, C., Feng, X., Wang, L., Wang, L., Gu, R., Ni, A., . . . Luo, Y.-J. (2019). The neural signatures of egocentric bias in normative decision-making. Brain Imaging and behavior, 13(3), 685-698.

Feng, C., Luo, Y. J., \& Krueger, F. (2015). Neural signatures of fairness $\square$ related normative decision making in the ultimatum game: A coordinate $\square$ based meta $\square$ analysis. Human brain mapping, 36(2), 591-602.

Fite, P. J., Stoppelbein, L., \& Greening, L. (2009). Proactive and reactive aggression in a child psychiatric inpatient population: Relations to psychopathic characteristics. Criminal Justice and Behavior, 36(5), 481-493.

Fouragnan, E., Retzler, C., \& Philiastides, M. G. (2018). Separate neural representations of prediction error valence and surprise: Evidence from an fMRI meta $\square$ analysis. Human brain mapping, 39(7), 2887-2906.

Friebel, U., Eickhoff, S. B., \& Lotze, M. (2011). Coordinate-based meta-analysis of experimentally induced and chronic persistent neuropathic pain. Neuroimage, 58(4), 1070-1080.

Frogner, L., Andershed, A.-K., \& Andershed, H. (2018). Psychopathic personality works better than CU traits for predicting fearlessness and ADHD symptoms among children with conduct problems. Journal of Psychopathology and Behavioral Assessment, 40(1), 26-39.

Fullana, M., Harrison, B., Soriano-Mas, C., Vervliet, B., Cardoner, N., Àvila-Parcet, A., \& Radua, J. (2016). Neural signatures of human fear conditioning: an updated and extended meta-analysis of fMRI studies. Molecular psychiatry, 21(4), 500-508.

Gallucci, A., Riva, P., Lauro, L. J. R., \& Bushman, B. J. (2020). Stimulating the ventrolateral prefrontal cortex (VLPFC) modulates frustration-induced aggression: A tDCS experiment. Brain stimulation, 13(2), 302-309. 
medRxiv preprint doi: https://doi.org/10.1101/2021.05.12.21257119; this version posted May 19, 2021. The copyright holder for this preprint

(which was not certified by peer review) is the author/funder, who has granted medRxiv a license to display the preprint in perpetuity. It is made available under a CC-BY-NC 4.0 International license .

Gallup, G. G. (1965). Aggression in rats as a function of frustrative nonreward in a straight alley. Psychonomic Science, 3(1), 99-100.

Ghaziri, J., Tucholka, A., Girard, G., Boucher, O., Houde, J.-C., Descoteaux, M., . . Nguyen, D. K. (2018). Subcortical structural connectivity of insular subregions. Scientific reports, $8(1), 1-12$.

Gilam, G., Abend, R., Gurevitch, G., Erdman, A., Baker, H., Ben-Zion, Z., \& Hendler, T. (2018). Attenuating anger and aggression with neuromodulation of the vmPFC: A simultaneous tDCS-fMRI study. cortex, 109, 156-170.

Gradin, V., Pérez, A., MacFarlane, J., Cavin, I., Waiter, G., Engelmann, J., . . Steele, J. (2015). Abnormal brain responses to social fairness in depression: an fMRI study using the Ultimatum Game. Psychological medicine, 45(6), 1241-1251.

Gradin, V. B., Waiter, G., O'Connor, A., Romaniuk, L., Stickle, C., Matthews, K., . . Steele, J. D. (2013). Salience network-midbrain dysconnectivity and blunted reward signals in schizophrenia. Psychiatry Research: Neuroimaging, 211(2), 104-111.

Graziano, P. A., \& Garcia, A. (2016). Attention-deficit hyperactivity disorder and children's emotion dysregulation: A meta-analysis. Clinical psychology review, 46, 106-123.

Gregg, T. R., \& Siegel, A. (2001). Brain structures and neurotansmitters regulating aggression in cats: implications for human aggression. Progress in neuro-psychopharmacology and biological psychiatry, 25(1), 91-140.

Grupe, D. W., Wielgosz, J., Davidson, R. J., \& Nitschke, J. B. (2016). Neurobiological correlates of distinct PTSD symptom profiles during threat anticipation in combat veterans. Psychological medicine, 46(9), 1885.

Gu, X., Hof, P. R., Friston, K. J., \& Fan, J. (2013). Anterior insular cortex and emotional awareness. Journal of Comparative Neurology, 521(15), 3371-3388.

Haber, S. N. (2016). Corticostriatal circuitry. Dialogues in clinical neuroscience, 18(1), 7.

Haber, S. N., \& Knutson, B. (2010). The reward circuit: linking primate anatomy and human imaging. Neuropsychopharmacology, 35(1), 4-26.

Hardwick, R. M., Caspers, S., Eickhoff, S. B., \& Swinnen, S. P. (2018). Neural correlates of action: Comparing meta-analyses of imagery, observation, and execution. Neuroscience \& Biobehavioral Reviews, 94, 31-44.

Harenski, C. L., \& Kiehl, K. A. (2010). Reactive aggression in psychopathy and the role of frustration: Susceptibility, experience, and control. British journal of psychology (London, England: 1953), 101(0 3), 401.

Harenski, C. L., Thornton, D. M., Harenski, K. A., Decety, J., \& Kiehl, K. A. (2012). Increased frontotemporal activation during pain observation in sexual sadism: Preliminary findings. Archives of general psychiatry, 69(3), 283-292.

Harlé, K. M., Chang, L. J., van't Wout, M., \& Sanfey, A. G. (2012). The neural mechanisms of affect infusion in social economic decision-making: a mediating role of the anterior insula. Neuroimage, 61(1), 32-40.

Harlé, K. M., \& Sanfey, A. G. (2007). Incidental sadness biases social economic decisions in the Ultimatum Game. Emotion, 7(4), 876.

Hart, G., Leung, B. K., \& Balleine, B. W. (2014). Dorsal and ventral streams: the distinct role of striatal subregions in the acquisition and performance of goal-directed actions. Neurobiology of learning and memory, 108, 104-118.

Hartley, C. A., \& Phelps, E. A. (2010). Changing fear: the neurocircuitry of emotion regulation. Neuropsychopharmacology, 35(1), 136. 
medRxiv preprint doi: https://doi.org/10.1101/2021.05.12.21257119; this version posted May 19, 2021. The copyright holder for this preprint

(which was not certified by peer review) is the author/funder, who has granted medRxiv a license to display the preprint in perpetuity. It is made available under a CC-BY-NC 4.0 International license .

Herpertz, S. C., Nagy, K., Ueltzhöffer, K., Schmitt, R., Mancke, F., Schmahl, C., \& Bertsch, K. (2017). Brain mechanisms underlying reactive aggression in borderline personality disorder-sex matters. Biological psychiatry, 82(4), 257-266.

Hershberger, A. R., Um, M., \& Cyders, M. A. (2017). The relationship between the UPPS-P impulsive personality traits and substance use psychotherapy outcomes: A meta-analysis. Drug and Alcohol Dependence, 178, 408-416.

Hétu, S., Grégoire, M., Saimpont, A., Coll, M.-P., Eugène, F., Michon, P.-E., \& Jackson, P. L. (2013). The neural network of motor imagery: an ALE meta-analysis. Neuroscience \& Biobehavioral Reviews, 37(5), 930-949.

Hiser, J., \& Koenigs, M. (2018). The multifaceted role of the ventromedial prefrontal cortex in emotion, decision making, social cognition, and psychopathology. Biological psychiatry, 83(8), 638-647.

Hyde, L. W., Shaw, D. S., \& Hariri, A. R. (2013). Understanding youth antisocial behavior using neuroscience through a developmental psychopathology lens: Review, integration, and directions for research. Developmental Review, 33(3), 168-223.

Izquierdo, A., Suda, R. K., \& Murray, E. A. (2005). Comparison of the effects of bilateral orbital prefrontal cortex lesions and amygdala lesions on emotional responses in rhesus monkeys. Journal of Neuroscience, 25(37), 8534-8542.

Jensen, K. B., Regenbogen, C., Ohse, M. C., Frasnelli, J., Freiherr, J., \& Lundström, J. N. (2016). Brain activations during pain: a neuroimaging meta-analysis of patients with pain and healthy controls. Pain, 157(6), 1279-1286.

Kim, M. J., Loucks, R. A., Palmer, A. L., Brown, A. C., Solomon, K. M., Marchante, A. N., \& Whalen, P. J. (2011). The structural and functional connectivity of the amygdala: from normal emotion to pathological anxiety. Behavioural brain research, 223(2), 403-410.

Kirkby, R. J., \& Kimble, D. P. (1968). Avoidance and escape behavior following striatal lesions in the rat. Experimental neurology, 20(2), 215-227.

Knutson, B., Fong, G. W., Adams, C. M., Varner, J. L., \& Hommer, D. (2001). Dissociation of reward anticipation and outcome with event-related fMRI. Neuroreport, 12(17), 36833687.

Knutson, B., Fong, G. W., Bennett, S. M., Adams, C. M., \& Hommer, D. (2003). A region of mesial prefrontal cortex tracks monetarily rewarding outcomes: characterization with rapid event-related fMRI. Neuroimage, 18(2), 263-272.

Kober, H., Barrett, L. F., Joseph, J., Bliss-Moreau, E., Lindquist, K., \& Wager, T. D. (2008). Functional grouping and cortical-subcortical interactions in emotion: a meta-analysis of neuroimaging studies. Neuroimage, 42(2), 998-1031.

Koenigs, M., Kruepke, M., \& Newman, J. P. (2010). Economic decision-making in psychopathy: a comparison with ventromedial prefrontal lesion patients. Neuropsychologia, 48(7), 2198-2204.

Kohls, G., Baumann, S., Gundlach, M., Scharke, W., Bernhard, A., Martinelli, A., . . Oldenhof, H. (2020). Investigating sex differences in emotion recognition, learning, and regulation among youths with conduct disorder. Journal of the American Academy of Child \& Adolescent Psychiatry, 59(2), 263-273.

Krupp, D. B., Sewall, L. A., Lalumière, M. L., Sheriff, C., \& Harris, G. T. (2012). Nepotistic patterns of violent psychopathy: evidence for adaptation? Frontiers in psychology, 3, 305.

Kuniishi, H., Ichisaka, S., Matsuda, S., Futora, E., Harada, R., \& Hata, Y. (2017). Chronic inactivation of the orbitofrontal cortex increases anxiety-like behavior and impulsive 
medRxiv preprint doi: https://doi.org/10.1101/2021.05.12.21257119; this version posted May 19, 2021. The copyright holder for this preprint

(which was not certified by peer review) is the author/funder, who has granted medRxiv a license to display the preprint in perpetuity.

It is made available under a CC-BY-NC 4.0 International license .

aggression, but decreases depression-like behavior in rats. Frontiers in Behavioral Neuroscience, 10, 250.

Lamm, C., Decety, J., \& Singer, T. (2011). Meta-analytic evidence for common and distinct neural networks associated with directly experienced pain and empathy for pain. Neuroimage, 54(3), 2492-2502.

Lanz, S., Seifert, F., \& Maihöfner, C. (2011). Brain activity associated with pain, hyperalgesia and allodynia: an ALE meta-analysis. Journal of Neural Transmission (Vienna, Austria: 1996), 118(8), 1139-1154.

Leh, S. E., Ptito, A., Chakravarty, M. M., \& Strafella, A. P. (2007). Fronto-striatal connections in the human brain: a probabilistic diffusion tractography study. Neuroscience letters, 419(2), 113-118.

Leibenluft, E. (2017). Pediatric irritability: a systems neuroscience approach. Trends in cognitive sciences, 21(4), 277-289.

Lickley, R. A., \& Sebastian, C. L. (2018). The neural basis of reactive aggression and its development in adolescence. Psychology, Crime \& Law, 24(3), 313-333.

Liu, C., Chai, J. W., \& Yu, R. (2016). Negative incidental emotions augment fairness sensitivity. Scientific reports, 6(1), 1-8.

Liu, X., Eickhoff, S. B., Caspers, S., Wu, J., Genon, S., Hoffstaedter, F., . . . Chen, J. (2021). Functional parcellation of human and macaque striatum reveals human-specific connectivity in the dorsal caudate. Neuroimage, 118006.

Liu, X., Hairston, J., Schrier, M., \& Fan, J. (2011). Common and distinct networks underlying reward valence and processing stages: a meta-analysis of functional neuroimaging studies. Neuroscience \& Biobehavioral Reviews, 35(5), 1219-1236.

Lovick, T. (1993). The periaqueductal gray-rostral medulla connection in the defence reaction: efferent pathways and descending control mechanisms. Behavioural brain research, 58(1-2), 19-25.

Marsh, A. A., Finger, E. C., Fowler, K. A., Jurkowitz, I. T., Schechter, J. C., Henry, H. Y., . . . Blair, R. J. R. (2011). Reduced amygdala-orbitofrontal connectivity during moral judgments in youths with disruptive behavior disorders and psychopathic traits. Psychiatry Research: Neuroimaging, 194(3), 279-286.

Marsh, A. A., Finger, E. C., Mitchell, D. G., Reid, M. E., Sims, C., Kosson, D. S., . . Blair, R. (2008). Reduced amygdala response to fearful expressions in children and adolescents with callous-unemotional traits and disruptive behavior disorders. American Journal of Psychiatry, 165(6), 712-720.

McClure, S. M., Berns, G. S., \& Montague, P. R. (2003). Temporal prediction errors in a passive learning task activate human striatum. Neuron, 38(2), 339-346.

McNorgan, C. (2012). A meta-analytic review of multisensory imagery identifies the neural correlates of modality-specific and modality-general imagery. Frontiers in Human Neuroscience, 6, 285.

Mechias, M.-L., Etkin, A., \& Kalisch, R. (2010). A meta-analysis of instructed fear studies: implications for conscious appraisal of threat. Neuroimage, 49(2), 1760-1768.

Menon, V., Gallardo, G., Pinsk, M. A., Nguyen, V.-D., Li, J.-R., Cai, W., \& Wassermann, D. (2020). Microstructural organization of human insula is linked to its macrofunctional circuitry and predicts cognitive control. Elife, 9, e53470. 
medRxiv preprint doi: https://doi.org/10.1101/2021.05.12.21257119; this version posted May 19, 2021. The copyright holder for this preprint

(which was not certified by peer review) is the author/funder, who has granted medRxiv a license to display the preprint in perpetuity. It is made available under a CC-BY-NC 4.0 International license.

Milad, M. R., Pitman, R. K., Ellis, C. B., Gold, A. L., Shin, L. M., Lasko, N. B., . . Rauch, S. L. (2009). Neurobiological basis of failure to recall extinction memory in posttraumatic stress disorder. Biological psychiatry, 66(12), 1075-1082.

Mobbs, D., Petrovic, P., Marchant, J. L., Hassabis, D., Weiskopf, N., Seymour, B., . . Frith, C. D. (2007). When fear is near: threat imminence elicits prefrontal-periaqueductal gray shifts in humans. Science, 317(5841), 1079-1083.

Morawetz, C., Bode, S., Derntl, B., \& Heekeren, H. R. (2017). The effect of strategies, goals and stimulus material on the neural mechanisms of emotion regulation: a meta-analysis of fMRI studies. Neuroscience \& Biobehavioral Reviews, 72, 111-128.

Motzkin, J. C., Philippi, C. L., Wolf, R. C., Baskaya, M. K., \& Koenigs, M. (2015). Ventromedial prefrontal cortex is critical for the regulation of amygdala activity in humans. Biological psychiatry, 77(3), 276-284.

Murray, L., Waller, R., \& Hyde, L. W. (2018). A systematic review examining the link between psychopathic personality traits, antisocial behavior, and neural reactivity during reward and loss processing. Personality Disorders: Theory, Research, and Treatment, 9(6), 497.

Nomi, J. S., Farrant, K., Damaraju, E., Rachakonda, S., Calhoun, V. D., \& Uddin, L. Q. (2016). Dynamic functional network connectivity reveals unique and overlapping profiles of insula subdivisions. Human brain mapping, 37(5), 1770-1787.

O'Doherty, J., Dayan, P., Schultz, J., Deichmann, R., Friston, K., \& Dolan, R. J. (2004). Dissociable roles of ventral and dorsal striatum in instrumental conditioning. Science, 304(5669), 452-454.

Oldham, S., Murawski, C., Fornito, A., Youssef, G., Yücel, M., \& Lorenzetti, V. (2018). The anticipation and outcome phases of reward and loss processing: A neuroimaging meta $\square$ analysis of the monetary incentive delay task. Human brain mapping, 39(8), 33983418.

Ong, W.-Y., Stohler, C. S., \& Herr, D. R. (2019). Role of the prefrontal cortex in pain processing. Molecular neurobiology, 56(2), 1137-1166.

Osumi, T., \& Ohira, H. (2010). The positive side of psychopathy: Emotional detachment in psychopathy and rational decision-making in the ultimatum game. Personality and Individual Differences, 49(5), 451-456.

Panksepp, J. (2004). Affective neuroscience: The foundations of human and animal emotions: Oxford university press.

Panksepp, J., \& Zellner, M. R. (2004). Towards a neurobiologically based unified theory of aggression. REVUE INTERNATIONALE DE PSYCHOLOGIE SOCIALE., 17, 37-62.

Paz, V., Nicolaisen-Sobesky, E., Collado, E., Horta, S., Rey, C., Rivero, M., . . . Pérez, A. (2017). Effect of self-esteem on social interactions during the Ultimatum Game. Psychiatry Research, 252, 247-255.

Perino, M. T., Moreira, J. F. G., \& Telzer, E. H. (2019). Links between adolescent bullying and neural activation to viewing social exclusion. Cognitive, Affective, \& Behavioral Neuroscience, 19(6), 1467-1478.

Pessiglione, M., Seymour, B., Flandin, G., Dolan, R. J., \& Frith, C. D. (2006). Dopaminedependent prediction errors underpin reward-seeking behaviour in humans. Nature, 442(7106), 1042-1045.

Poeppl, T. B., Donges, M. R., Mokros, A., Rupprecht, R., Fox, P. T., Laird, A. R., . . Eickhoff, S. B. (2019). A view behind the mask of sanity: meta-analysis of aberrant brain activity in psychopaths. Molecular psychiatry, 24(3), 463. 
medRxiv preprint doi: https://doi.org/10.1101/2021.05.12.21257119; this version posted May 19, 2021. The copyright holder for this preprint

(which was not certified by peer review) is the author/funder, who has granted medRxiv a license to display the preprint in perpetuity. It is made available under a CC-BY-NC 4.0 International license .

Puiu, A. A., Wudarczyk, O., Kohls, G., Bzdok, D., Herpertz $\square$ Dahlmann, B., \& Konrad, K. (2020). Meta $\square$ analytic evidence for a joint neural mechanism underlying response inhibition and state anger. Human brain mapping, 41(11), 3147-3160.

Reidy, D. E., Shelley-Tremblay, J. F., \& Lilienfeld, S. O. (2011). Psychopathy, reactive aggression, and precarious proclamations: A review of behavioral, cognitive, and biological research. Aggression and Violent Behavior, 16(6), 512-524.

Riva, P., Gabbiadini, A., Lauro, L. J. R., Andrighetto, L., Volpato, C., \& Bushman, B. J. (2017). Neuromodulation can reduce aggressive behavior elicited by violent video games. Cognitive, Affective, \& Behavioral Neuroscience, 17(2), 452-459.

Riva, P., Romero Lauro, L. J., DeWall, C. N., Chester, D. S., \& Bushman, B. J. (2015). Reducing aggressive responses to social exclusion using transcranial direct current stimulation. Social cognitive and affective neuroscience, 10(3), 352-356.

Rogers, J. C., \& De Brito, S. A. (2016). Cortical and subcortical gray matter volume in youths with conduct problems: a meta-analysis. JAMA psychiatry, 73(1), 64-72.

Ross, A. J., Roule, A. L., Deveney, C. M., Towbin, K. E., Brotman, M. A., Leibenluft, E., \& Tseng, W. L. (2020). A preliminary study on functional activation and connectivity during frustration in youths with bipolar disorder. Bipolar Disorders.

Schneider, B., \& Koenigs, M. (2017). Human lesion studies of ventromedial prefrontal cortex. Neuropsychologia, 107, 84-93.

Shiba, Y., Kim, C., Santangelo, A. M., \& Roberts, A. C. (2015). Lesions of either anterior orbitofrontal cortex or ventrolateral prefrontal cortex in marmoset monkeys heighten innate fear and attenuate active coping behaviors to predator threat. Frontiers in systems neuroscience, 8, 250.

Sorella, S., Grecucci, A., Piretti, L., \& Job, R. (2021). Do anger perception and the experience of anger share common neural mechanisms? Coordinate-based meta-analytic evidence of similar and different mechanisms from functional neuroimaging studies. Neuroimage, 117777.

Spaniol, J., Di Muro, F., \& Ciaramelli, E. (2019). Differential impact of ventromedial prefrontal cortex damage on "hot" and "cold" decisions under risk. Cognitive, Affective, \& Behavioral Neuroscience, 19(3), 477-489.

Studer, B., Manes, F., Humphreys, G., Robbins, T. W., \& Clark, L. (2015). Risk-sensitive decision-making in patients with posterior parietal and ventromedial prefrontal cortex injury. Cerebral Cortex, 25(1), 1-9.

Tanasescu, R., Cottam, W. J., Condon, L., Tench, C. R., \& Auer, D. P. (2016). Functional reorganisation in chronic pain and neural correlates of pain sensitisation: a coordinate based meta-analysis of 266 cutaneous pain fMRI studies. Neuroscience \& Biobehavioral Reviews, 68, 120-133.

Treadway, M. T., Buckholtz, J. W., Martin, J. W., Jan, K., Asplund, C. L., Ginther, M. R., . . . Marois, R. (2014). Corticolimbic gating of emotion-driven punishment. Nature neuroscience, 17(9), 1270-1275.

Uddin, L. Q., Yeo, B. T., \& Spreng, R. N. (2019). Towards a universal taxonomy of macro-scale functional human brain networks. Brain topography, 32(6), 926-942.

van Heukelum, S., Tulva, K., Geers, F. E., van Dulm, S., Ruisch, I. H., Mill, J., . . Poelmans, G. (2021). A central role for anterior cingulate cortex in the control of pathological aggression. Current Biology. 
medRxiv preprint doi: https://doi.org/10.1101/2021.05.12.21257119; this version posted May 19, 2021. The copyright holder for this preprint

(which was not certified by peer review) is the author/funder, who has granted medRxiv a license to display the preprint in perpetuity. It is made available under a CC-BY-NC 4.0 International license.

van't Wout, M., Chang, L. J., \& Sanfey, A. G. (2010). The influence of emotion regulation on social interactive decision-making. Emotion, 10(6), 815.

VanElzakker, M. B., Staples-Bradley, L. K., \& Shin, L. M. (2018). The neurocircuitry of fear and PTSD. In Sleep and Combat-Related Post Traumatic Stress Disorder (pp. 111-125): Springer.

Vergallito, A., Riva, P., Pisoni, A., \& Lauro, L. J. R. (2018). Modulation of negative emotions through anodal tDCS over the right ventrolateral prefrontal cortex. Neuropsychologia, $119,128-135$.

Viding, E., Fontaine, N. M., \& McCrory, E. J. (2012). Antisocial behaviour in children with and without callous-unemotional traits. Journal of the Royal Society of Medicine, 105(5), 195-200.

Vierck, C. J., Whitsel, B. L., Favorov, O. V., Brown, A. W., \& Tommerdahl, M. (2013). Role of primary somatosensory cortex in the coding of pain. PAIN®, 154(3), 334-344.

Vindas, M. A., Folkedal, O., Kristiansen, T. S., Stien, L. H., Braastad, B. O., Mayer, I., \& Øverli, $\emptyset$. (2012). Omission of expected reward agitates Atlantic salmon (Salmo salar). Animal Cognition, 15(5), 903-911.

Vindas, M. A., Johansen, I. B., Vela-Avitua, S., Nørstrud, K. S., Aalgaard, M., Braastad, B. O., . . . Øverli, Ø. (2014). Frustrative reward omission increases aggressive behaviour of inferior fighters. Proceedings of the Royal Society B: Biological Sciences, 281(1784), 20140300.

Wager, T. D., Barrett, L. F., Bliss-Moreau, E., Lindquist, K. A., Duncan, S., Kober, H., . . Mize, J. (2008). The neuroimaging of emotion.

Waller, R., \& Wagner, N. (2019). The Sensitivity to Threat and Affiliative Reward (STAR) model and the development of callous-unemotional traits. Neuroscience \& Biobehavioral Reviews, 107, 656-671.

White, S. F., Pope, K., Sinclair, S., Fowler, K. A., Brislin, S. J., Williams, W. C., . . Blair, R. J. R. (2013). Disrupted expected value and prediction error signaling in youths with disruptive behavior disorders during a passive avoidance task. American Journal of Psychiatry, 170(3), 315-323.

Winocur, G. (1974). Functional dissociation within the caudate nucleus of rats. Journal of comparative and physiological psychology, 86(3), 432.

Wong, T. Y., Sid, A., Wensing, T., Eickhoff, S. B., Habel, U., Gur, R. C., \& Nickl-Jockschat, T. (2019). Neural networks of aggression: ALE meta-analyses on trait and elicited aggression. Brain Structure and Function, 224(1), 133-148.

Xu, A., Larsen, B., Baller, E. B., Scott, J. C., Sharma, V., Adebimpe, A., . . Woolf, C. J. (2020). Convergent neural representations of experimentally-induced acute pain in healthy volunteers: A large-scale fMRI meta-analysis. Neuroscience \& Biobehavioral Reviews, $112,300-323$.

Yarkoni, T., Poldrack, R. A., Nichols, T. E., Van Essen, D. C., \& Wager, T. D. (2011). Largescale automated synthesis of human functional neuroimaging data. Nature methods, $8(8)$, 665-670.

Yoder, K., Harenski, C., Kiehl, K., \& Decety, J. (2015). Neural networks underlying implicit and explicit moral evaluations in psychopathy. Translational psychiatry, 5(8), e625-e625.

Yu, R., Mobbs, D., Seymour, B., Rowe, J. B., \& Calder, A. J. (2014). The neural signature of escalating frustration in humans. cortex, 54, 165-178. 
medRxiv preprint doi: https://doi.org/10.1101/2021.05.12.21257119; this version posted May 19, 2021. The copyright holder for this preprint (which was not certified by peer review) is the author/funder, who has granted medRxiv a license to display the preprint in perpetuity.

$$
\text { It is made available under a CC-BY-NC } 4.0 \text { International license. }
$$



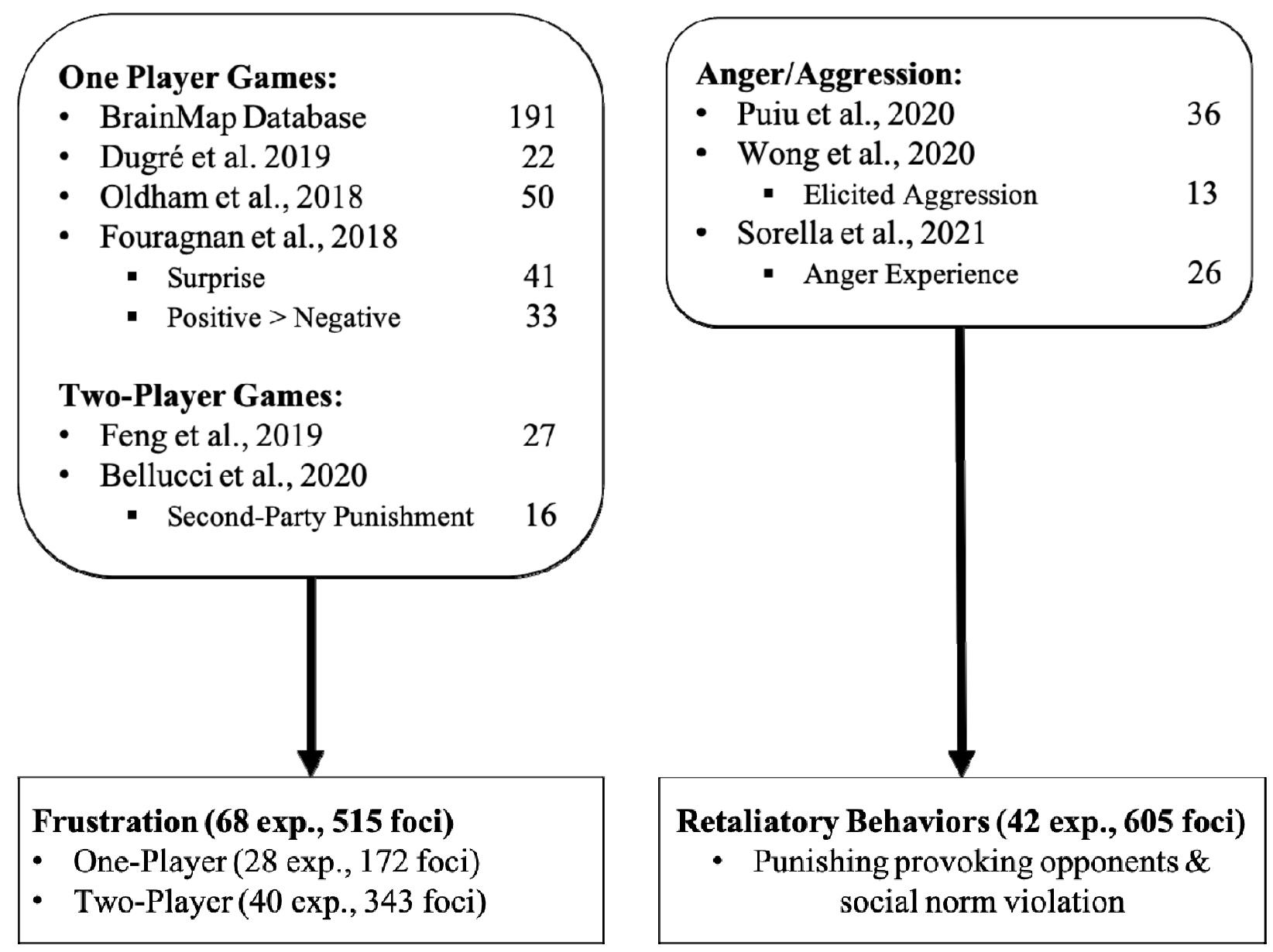

Figure 1. Flowchart of the literature search for Frustration and Retaliatory Behaviors. 
medRxiv preprint doi: https://doi.org/10.1101/2021.05.12.21257119; this version posted May 19, 2021. The copyright holder for this preprint (which was not certified by peer review) is the author/funder, who has granted medRxiv a license to display the preprint in perpetuity.

It is made available under a CC-BY-NC 4.0 International license .

Table 1. Main Effect of Frustration and Retaliatory Behaviors

\begin{tabular}{|c|c|c|c|c|c|}
\hline \multirow[b]{2}{*}{ Main Peaks } & \multicolumn{3}{|c|}{ MNI Coordinates } & \multirow[b]{2}{*}{ ALE } & \multirow[b]{2}{*}{ Voxels } \\
\hline & $\mathrm{X}$ & $\mathrm{Y}$ & $\mathrm{Z}$ & & \\
\hline \multicolumn{6}{|l|}{ Frustration $_{\text {INCREASED }}$} \\
\hline dACC/aMCC/pre-SMA & 8 & 24 & 36 & 0.0334 & 1569 \\
\hline FIC & 36 & 22 & -4 & 0.0528 & 1051 \\
\hline FIC & -30 & 22 & 0 & 0.0499 & 1000 \\
\hline $\mathrm{dmPFC} \dagger$ & -8 & 60 & 20 & 0.0279 & 54 \\
\hline Thalamus (MD) $\dagger$ & 4 & -12 & 4 & 0.0212 & 47 \\
\hline Amygdala $\dagger$ & -18 & -4 & -10 & 0.0197 & 24 \\
\hline $\mathrm{PAG}_{\dagger}+$ & -4 & -28 & -4 & 0.0205 & 21 \\
\hline \multicolumn{6}{|l|}{ Frustration $_{\text {DECREASED }}$} \\
\hline vStriatum & 12 & 10 & -8 & 0.0455 & 2144 \\
\hline vStriatum & -10 & 10 & -8 & 0.0357 & - \\
\hline $\mathrm{mOFC} / \mathrm{vmPFC}$ & 2 & 46 & -12 & 0.0239 & 940 \\
\hline PCC/Precuneus & -6 & -58 & 18 & 0.0158 & 451 \\
\hline \multicolumn{6}{|l|}{ Retaliatory Behaviors } \\
\hline FIC & 30 & 20 & 2 & 0.0341 & 288 \\
\hline FIC & -30 & 18 & -14 & 0.0365 & 274 \\
\hline dStriatum & 12 & 14 & 10 & 0.0293 & 159 \\
\hline postcentral; IPL & -38 & -32 & 62 & 0.0251 & 126 \\
\hline aMCC; pre-SMA; SMA & -4 & 16 & 52 & 0.0242 & 121 \\
\hline $\mathrm{PAG} \dagger$ & -4 & -20 & -6 & 0.0246 & 44 \\
\hline Thalamus (VPL) $\dagger$ & -14 & -22 & 8 & 0.0195 & 23 \\
\hline
\end{tabular}

Note. $\dagger=$ Peaks that emerged when using a more liberal statistical threshold ( $p<0.001$ uncorrected). All other peaks are reported at $p<0.001$ voxel and $c F W E<0.05$. 


\section{Decreased Activation in Frustrative Non-Reward}

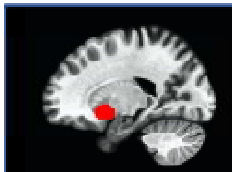

20

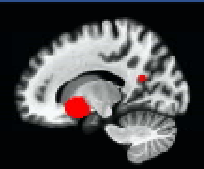

15

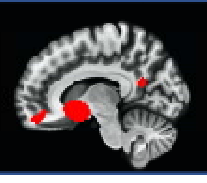

10

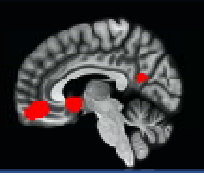

5

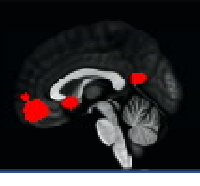

0

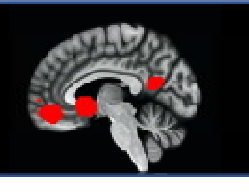

$-5$

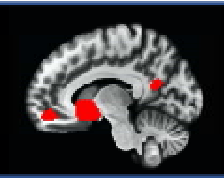

$-10$

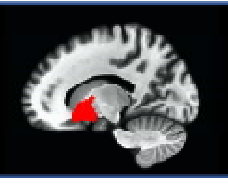

$-15$

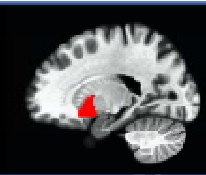

$-20$

Conjunction Between Frustration \& Retaliatory Behaviors

$\mathbf{R}$

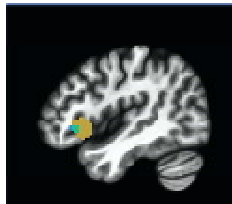

$\mathbf{L}$

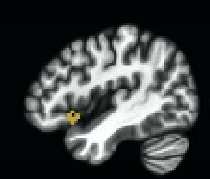

$+1-45$
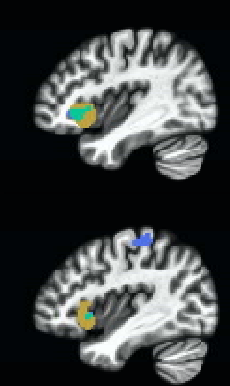

$+1-40$
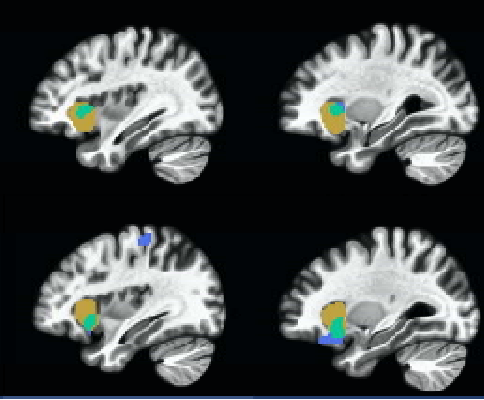

$+/-35$

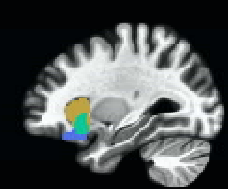

$+/-30$
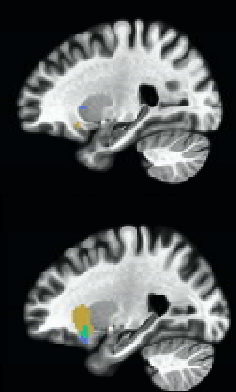

$+/-25$
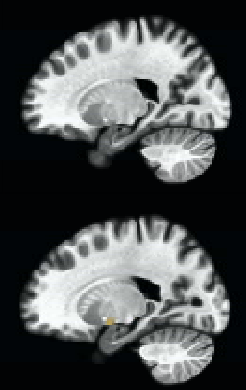

$+1-20$
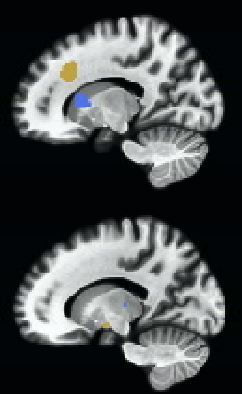

$+/-15$

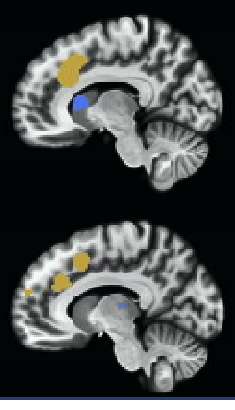

$+/-10$
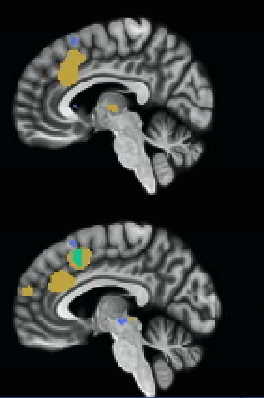

$+1-5$

Figure 2. Main results of the meta-analysis on frustration and retaliatory behaviors. Red = Decreased activation in the meta-analysis on frustrative non-reward. Yellow = Increased activation in the meta-analysis on frustrative non-reward. Blue $=$ Increased activation in the meta-analysis on retaliation. Green = results from the conjunction analysis between frustrative non-reward and retaliation. 


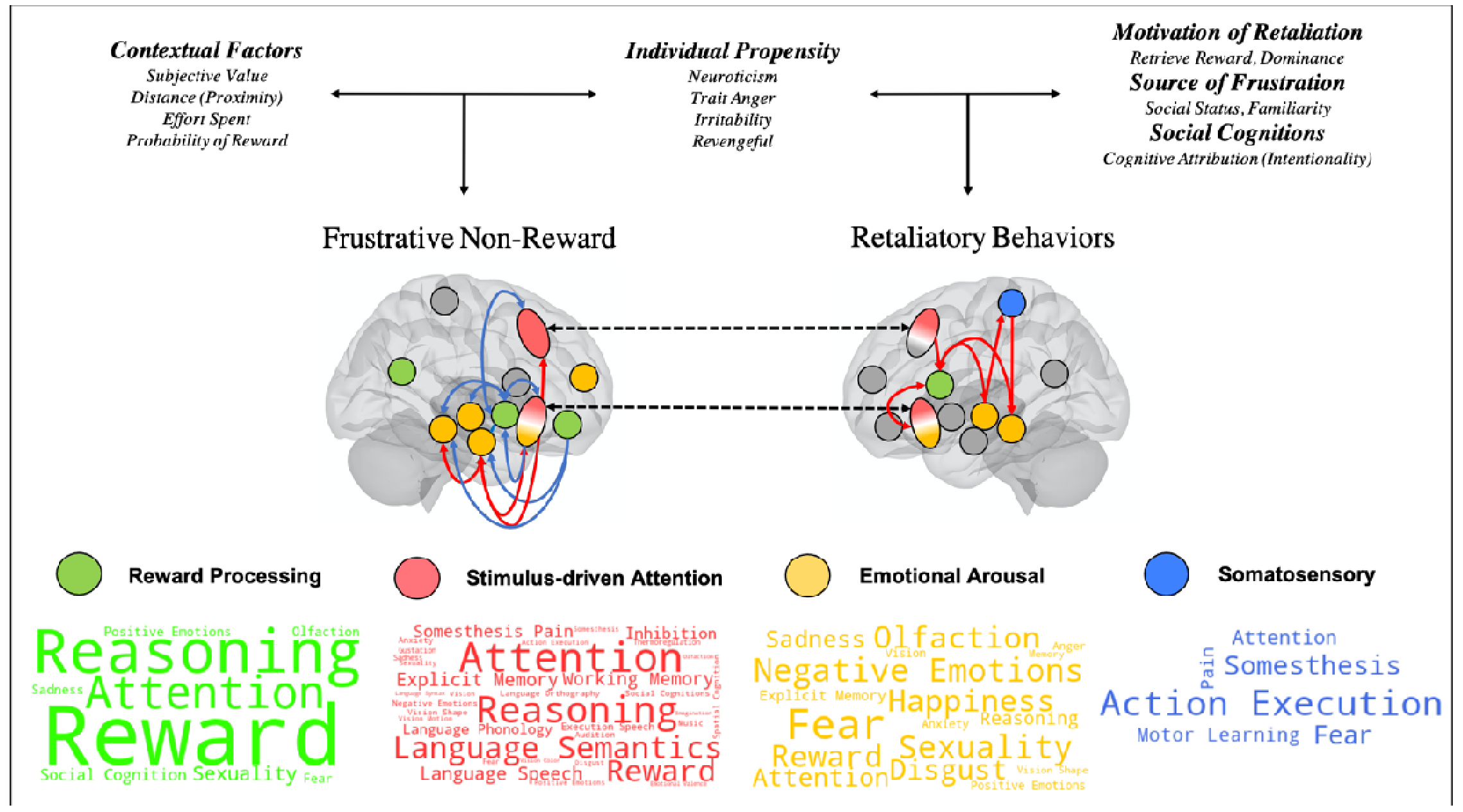

Figure 3. Summary of the neurobiological model of Frustration-based impulsive aggression. Lines represent interaction between subsystems as supported by literature. Blue line $=$ negative relationship between brain regions; Red lines $=$ positive relationship between brain regions. Black dotted line $=$ brain regions that significantly overlapped between frustrative non-reward and retaliatory behaviors. Word Cloud were produced using the Behavioral Analysis Plugin of the Multi-image Analysis GUI which utilize the BrainMap database (Lancaster et al., 2012). Bigger font represents higher Z-score. Every word presented in the Figure showed a statistically significant Z-Score (higher than 3.0) with Bonferroni correction for multiple comparison ( $<<0.05)$. 